\title{
Simulation of mineral dust aerosol with Piecewise Log-normal Approximation (PLA) in CanAM4-PAM
}

\author{
Y. Peng ${ }^{1}$, K. von Salzen ${ }^{2}$, and J. Li ${ }^{2}$ \\ ${ }^{1}$ School of Earth and Ocean Sciences, University of Victoria, Victoria, British Columbia, Canada \\ ${ }^{2}$ Canadian Centre for Climate Modelling and Analysis, Environment Canada, Victoria, British Columbia, Canada
}

Correspondence to: Y. Peng (yiran.peng@ec.gc.ca)

Received: 29 August 2011 - Published in Atmos. Chem. Phys. Discuss.: 22 September 2011

Revised: 18 May 2012 - Accepted: 11 July 2012 - Published: 1 August 2012

\begin{abstract}
A new size-resolved dust scheme based on the numerical method of piecewise log-normal approximation (PLA) was developed and implemented in the fourth generation of the Canadian Atmospheric Global Climate Model with the PLA Aerosol Model (CanAM4-PAM). The total simulated annual global dust emission is $2500 \mathrm{Tg} \mathrm{yr}^{-1}$, and the dust mass load is $19.3 \mathrm{Tg}$ for year 2000. Both are consistent with estimates from other models. Results from simulations are compared with multiple surface measurements near and away from dust source regions, validating the generation, transport and deposition of dust in the model. Most discrepancies between model results and surface measurements are due to unresolved aerosol processes. Biases in long-range transport are also contributing. Radiative properties of dust aerosol are derived from approximated parameters in two size modes using Mie theory. The simulated aerosol optical depth (AOD) is compared with satellite and surface remote sensing measurements and shows general agreement in terms of the dust distribution around sources. The model yields a dust AOD of 0.042 and dust aerosol direct radiative forcing (ADRF) of $-1.24 \mathrm{~W} \mathrm{~m}^{-2}$ respectively, which show good consistency with model estimates from other studies.
\end{abstract}

\section{Introduction}

Mineral dust aerosol is one of the important contributors to global aerosol loading (Textor et al., 2006) and radiative forcing (Kinne et al., 2006; Balkanski et al., 2007), originating from aeolian erosion in arid and semi-arid regions, going through complex atmospheric processes and exerting strong impacts on regional and global climates (e.g., Slingo et al., 2006; McFarlane et al., 2009; Li et al., 2007a,b).

Dust aerosols absorb and scatter both solar and terrestrial radiation. However, the direct radiative forcing of dust is still uncertain. Even the sign of this forcing is under debate. Most uncertainties are attributed to the calculation of optical properties, which are dependent upon the simulated dust fraction in different size modes (e.g., Kinne et al., 2006; Schulz et al., 2006). The vertical distribution of dust is also an uncertain factor for estimation of longwave radiative forcing (Solomon et al., 2007).

Dust aerosols may act as cloud condensation nuclei (CCN) if coated with soluble aerosols (such as sulfate), and affect cloud droplet number and size, thus inhibiting precipitation (e.g., Rosenfeld et al., 2001). Dust is also an efficient ice nucleus (IN) (Sassen, 2002) and may have diverse effects in mesoscale cloud systems by changing cloud properties under different temperature and humidity conditions (Min et al., 2009). Additionally, dust aerosols are a source of iron, which, once deposited, affects marine biogeochemical processes that contribute to the uptake of carbon by the ocean (Jickells et al., 2005).

Global climate models (GCMs) have been used in several studies for simulation of the global dust cycle. By applying bulk microphysics of atmospheric aerosols (e.g., only the total number or/and mass of aerosols are traced through modelled processes), the first-order pattern of the dust distribution can be reproduced (e.g., Tegen and Fung, 1994; Reader et al., 1999). Huneeus et al. (2011) conducts a multiparameter and multi-model intercomparison of global dust models, and suggests that size-resolved information is a significant factor in improving the dust simulation. Both bin 
and modal methods have been introduced in recent GCMs to simulate size-segregated emission and transport processes of dust aerosol (e.g., Gong et al., 2003; Stier et al., 2005).

Current model results exhibit large variation in the dust aerosol simulations. Modeled dust annual emission amount ranges between 1000 and $3000 \mathrm{Tg} \mathrm{yr}^{-1}$ in different GCMs as summarized in Zender et al. (2004). Estimates of global, annual averaged dust emissions from AeroCom (Aerosol Comparisons between Observations and Models) are between 800 and $2500 \mathrm{Tg} \mathrm{yr}^{-1}$ for a dozen of models in year 2000 (Textor et al., 2006). Cakmur et al. (2006) used several global datasets of aerosol optical depth (AOD), dust surface concentration, deposition as well as particle size distributions, in order to constrain the magnitude of global dust cycle by minimizing the difference between NASA GISS (Goddard Institute for Space Studies) model results and observations, which yields an optimal global, annual emission flux from 1500 to $2600 \mathrm{Tg} \mathrm{yr}^{-1}$.

An estimate of dust dry mass load from AeroCom is $22.7 \pm 21 \mathrm{Tg}$ and $21.3 \pm 21 \mathrm{Tg}$ for two sets of experiments (Textor et al., 2006). The simulated optical depth of dust aerosol is between 0.009 and 0.054 , with a median of 0.032 from AeroCom (Kinne et al., 2006). Solomon et al. (2007) summarized dust direct radiative effects from several model studies, which range from -1.4 to $+0.2 \mathrm{~W} \mathrm{~m}^{-2}$. Estimates from other recent models also show an extensive range (e.g., Table 3).

Both surface measurements and satellite observations provide information about dust aerosol distribution and radiative properties on a global scale. Climatologically representative dust concentrations over remote oceans obtained from the network of the University of Miami (Prospero, 1996) are often used for model validation. AERONET (Aerosol Robotic Network) provides long-term measurements of aerosol optical properties with a global coverage (Holben et al., 1998, 2001) and derives the aerosol size distribution via an inversion algorithm (Dubovik and King, 2000). In addition, data extracted from AERONET and other sources are compiled and archived in the Dust Indicators and Records in Terrestrial and Marine Paleoenvironments (DIRTMAP) dataset (Kohfeld and Harrison, 2001) for deposition fluxes at numerous sites.

In recent decades, a global view of the aerosol distribution became available through satellite observations with passive remote sensors. For example, optical depth at $0.55 \mu \mathrm{m}$ is a commonly used product from MODIS (Moderate Resolution Imaging Spectroradiometer) and MISR (Multi-angle Imaging SpectroRadiometer) on board the NASA platform (Kaufman et al., 1997; Diner et al., 1998; Bothwell et al., 2002). The fraction of fine mode to the total aerosol optical depth, aerosol composition and particle size spectral information are also available from some satellite and remote sensing measurements. Retrieval data from satellite observations are usually analyzed by comparing with surface measurements to assure the data quality (e.g., Kahn et al., 2005).
In this study, we extend the fourth generation of the Canadian Atmospheric Global Climate Model (CanAM4) to include a new representation of the dust cycle. The numerical method of Piecewise Log-normal Approximation (PLA) is applied to simulate the size distribution of dust aerosol particles (von Salzen, 2006). In Sect. 2, the model setup and application of the PLA approach to dust simulations are described. Model results are validated by comparing with surface measurements of the dust size distribution, mass concentration and deposition rates, as shown in Sect. 3. Optical properties of dust are also calculated and compared with satellite observations in Sect. 4. Conclusions of this study and relevant discussions are presented in Sect. 5.

\section{Model description and PLA methodology}

The fourth generation of the Canadian Atmospheric Global Climate Model (CanAM4) represents the starting point for the development of a comprehensive earth system model at CCCma (Canadian Centre for Climate Modelling and Analysis, von Salzen et al., 2005). In this study, a spectral resolution with the triangular truncation at wave number of 47 (T47) is employed, which roughly corresponds to a horizontal resolution of $3.75^{\circ} \times 3.75^{\circ}$. Thirty-five vertical layers are used from the surface up to $1 \mathrm{hpa}$, with a resolution of about $100 \mathrm{~m}$ near the surface.

The Piecewise Log-normal Approximation (PLA) method (von Salzen, 2006) is used in CanAM4 to represent the aerosol size distribution. In the following, the newly created aerosol model will be referred to as PAM (PLA Aerosol Model).

Both bin and modal approaches are commonly used for size-resolved aerosol simulation in climate models. The PLA scheme takes advantage of both approaches by combining them into a hybrid method. The accuracy and computational efficiency of the PLA scheme have been demonstrated in von Salzen (2006). According to the PLA method, an aerosol number distribution can be expressed as:

$n(\varphi)=\sum_{i} n_{i}(\varphi)$

where $\varphi$ is a dimensionless size parameter $\varphi \equiv \ln \left(R_{\mathrm{p}} / R_{0}\right)$, $R_{\mathrm{p}}$ is the aerosol particle radius and $R_{0}$ is a reference radius of $1 \mu \mathrm{m}$.

In each section $i$, the aerosol number distribution is defined as:

$n_{i}(\varphi)=n_{0, i} \exp \left[-\psi_{i}\left(\varphi-\varphi_{0, i}\right)^{2}\right] H\left(\varphi-\varphi_{i-\frac{1}{2}}\right) H\left(\varphi_{i+\frac{1}{2}}-\varphi\right)$

where $n_{0, i}, \psi_{i}$ and $\varphi_{0, i}$ are fitting parameters, representing the magnitude, width and location of the maximum of the distribution respectively. $H(x)$ is the Heaviside step function whose purpose is to constrain the log-normal distribution in each section to the particle size range between $\varphi_{i-\frac{1}{2}}$ and 
$\varphi_{i+\frac{1}{2}}$. In CanAM4-PAM, we prescribe the width $\psi_{i}$. Fitting parameters $n_{0, i}$ and $\varphi_{0, i}$ for externally or internally mixed aerosol (with mass fraction of each internally mixed type of aerosol) are calculated at each model time step. These parameters are calculated from the integrated number $\left(N_{i}\right)$ and mass $\left(M_{i}\right)$ concentrations in each section (von Salzen, 2006). Both mass and number size distribution of dust particles are obtained through parameterization of physical processes in CanAM4-PAM. A more detailed description of the application to individual physical process is presented below.

\subsection{Dust emissions}

Dust aerosol originates from aeolian erosion in arid and semi-arid regions. A size-derived dust emission scheme (Marticorena and Bergametti, 1995; Marticorena et al., 1997) is used to provide an explicit representation of surface dust sources in CanAM4-PAM.

Emission of dust aerosols is not permitted in snow covered regions and vegetated areas over land in the model. The fractional dust source areas in the model grid cell is obtained from two off-line datasets. A potential dust source map is derived from a terrestrial biogeography model by including all non-forest biomes (Tegen et al., 2002), which is further combined with a global bare ground fraction dataset.

Dust emission is proportional to the bare ground fraction in CanAM4-PAM. The bare ground fraction over land is calculated offline in the Canadian Terrestrial Ecosystem Model (CTEM). CTEM (Arora and Boer, 2005) is a dynamic vegetation model, which includes nine plant function types (PFTs) such as trees, grass and crops. Areal fraction of CTEM PFTs are estimated with constraints derived from recent satellite observations. The bare ground fraction $\left(F_{\mathrm{bg}}\right)$ is obtained as:

$F_{\text {bg }}=1-\sum_{k=1}^{9} \mathrm{PFT}_{k}$

where $\mathrm{PFT}_{k}$ refers to the fraction of each vegetation type. This approach allows for changes in the composition of natural vegetation and changes due to human activities, with conservation of total area of all PFTs in a model grid cell (Wang et al., 2006). The annual variation of $F_{\mathrm{bg}}$ derived from current CTEM is less than $1 \%$. Thus we take the bare ground fraction averaged from 1850 to 2005 as a climatological representative constraint for this study. In a future version of CTEM, competition between bare and vegetated areas will be included, which may yield a more realistic input of time varying bare fraction for dust simulations.

Satellite observations provide useful information to estimate the seasonal and interannual changes in vegetation cover. A ten-year (1982 to 1993) monthly mean retrieval data of NDVI (normalized difference vegetation index) from the AVHRR (advanced very high resolution radiometer) satellite (Braswell et al., 1997) is taken to derive a potential dust source map by Tegen et al. (2002).

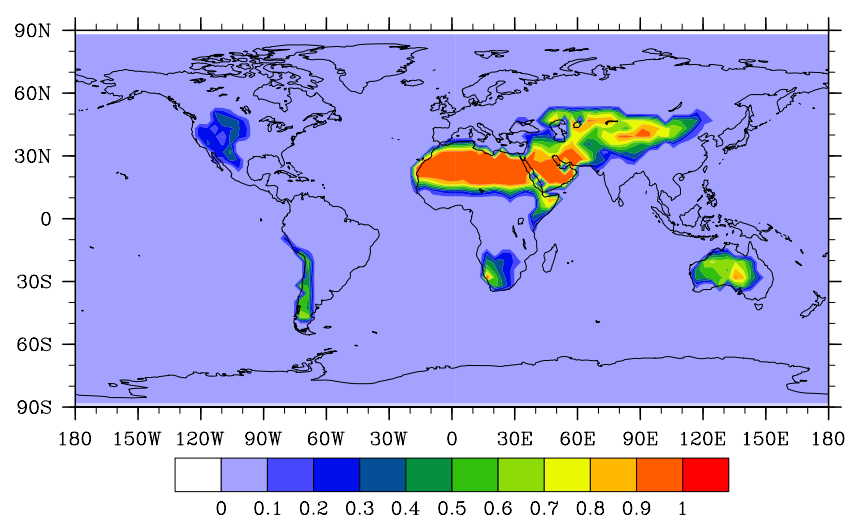

Fig. 1. An average over 12 monthly means of bare ground fraction $\left(F_{\text {bg }}\right)$ in potential dust source regions as prescribed in CanAM4PAM.

The CTEM bare ground fraction is applied in combination with the potential dust source map (Tegen et al., 2002) to mask out the non-dusty area in CanAM4-PAM. We prescribe 12 monthly means of derived bare ground fraction in CanAM4-PAM for this study. Figure 1 shows an average over these 12 monthly means of bare ground fraction in potential dust source regions.

Dust production is related to the motion of soil particles initiated by wind. The forces acting on particles include the weight, the interparticle cohesion forces, and the wind shear stress on the surface. The first two forces are dependent on the particle size as well as the soil moisture. The last force depends on the wind energy transferred to the erodible surface, which is controlled by the roughness elements on the surface (Marticorena and Bergametti, 1995). All forces together determine the minimum threshold friction velocity $U_{\mathrm{th}}^{*}$, which is required to initiate the particle motion.

A threshold value $\left(U_{\mathrm{th}}^{*}\right)$ is obtained in combination with the surface roughness and soil moisture in the model. A global map of surface aerodynamic roughness length is obtained from an analysis of measurements with the European Remote Sensing (ERS) satellite scatterometer (Prigent et al., 2005; Cheng et al., 2008) and included in the model as a climatological input field. Arid and semi-arid regions with high surface roughness require a large $U_{\mathrm{th}}^{*}$ to uplift soil particles. Because rough surface protects particles from the aeolian erosion, dust emission is inhibited.

As the soil moisture increases, soil water retention is responsible for the increase of the threshold wind friction velocity. Soil particles are adhesive to the surface in high moisture regions, thus dust emission is suppressed. Molecular adsorption on the soil particle surface as well as the capillary forces between particles are both taken into account. The influence of soil moisture on $U_{\mathrm{th}}^{*}$ is included in the model with a parameterization developed by Fécan et al. (1999). The soil moisture fraction in the parameterization is calculated in the Canadian Land Surface Scheme (CLASS) in CanAM4-PAM 
(Verseghy, 1991). The wetter the soil is, the stronger the soil retention force and the $U_{\mathrm{th}}^{*}$ (Cheng et al., 2008).

Both surface roughness and soil moisture modify the threshold wind friction velocity, which indicates how much the soil properties and local conditions favor the uplift of erodible particles. The dust emission flux is essentially determined by the wind friction velocity $\left(U^{*}\right)$, which is calculated as:

$U^{*} \propto \sqrt{U_{10}^{2}+U_{\text {gust }}^{2}}$

where $U_{10}$ and $U_{\text {gust }}$ are wind speed at the height of 10 metre and the gusty wind near the surface, respectively. Both wind components are predicted in the model at each time step. Once $U^{*}>U_{\mathrm{th}}^{*}$, the local wind stress is strong enough to overcome the particle weights and retention forces. The emitted flux of dust is proportional to $U^{* 3}$ (Marticorena and Bergametti, 1995). This power-dependence relation has been well-established and is applied in current climate models (e.g., Gong et al., 2003; Stier et al., 2005).

Twelve general soil types (Zobler, 1986) and five Asian soil types (Cheng et al., 2008) are considered in the model for the dust emission calculation. A global map of areal fraction for each soil type $\left(A_{\mathrm{st}}\right)$ is provided. Four soil populations of coarse sand, medium/fine sand, silt and clay are prescribed in four log-normal modes for each soil type. Compositional fractions of the four populations are also given for different soil types (Tegen et al., 2002). The soil particle radius $(r)$ is obtained in 192 size bins within [0.05,55] $\mu \mathrm{m}$ according to the prescribed distribution and composition for each soil type (st).

The emitted dust mass flux at a certain particle size is given as:

$D_{e}(r) \propto \sum_{\mathrm{st}=1}^{17} U^{*}\left(z_{0}, q_{\mathrm{s}}\right)^{3} A_{\mathrm{st}} S_{\mathrm{st}}(r)$

where $z_{0}$ and $q_{\mathrm{s}}$ denote the influences of surface roughness and soil moisture on $U^{*} . S_{\mathrm{st}}(r)$ is the mass size distribution of each soil type.

After weighting with the bare ground fraction $\left(F_{\mathrm{bg}}\right)$, sizeresolved mass fluxes of dust emission are integrated within two PLA sections. Particle radius in the first section is within $[0.1,1] \mu \mathrm{m}$ and within $[1,10] \mu \mathrm{m}$ in the second section.

$M_{1}=\int_{0.1}^{1} F_{\mathrm{bg}} D_{e}(r) \mathrm{d} r \quad M_{2}=\int_{1}^{10} F_{\mathrm{bg}} D_{e}(r) \mathrm{d} r$

Assuming spherical particles and a dust density of $2.65 \mathrm{~g} \mathrm{~cm}^{-3}$ globally, the number size distribution of emitted dust is available as well. Following Eq. (2), fitting parameters of the PLA size distribution are derived from the calculated mass and number of the dust emission size distribution in each grid cell. The width parameter $\left(\psi_{i}\right)$ in each PLA section is prescribed as 2.0 .

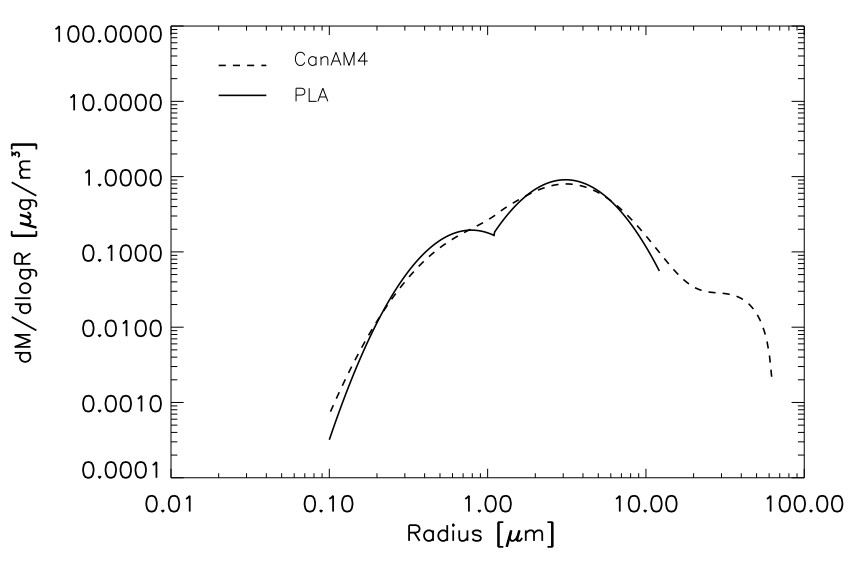

Fig. 2. Annual global mean size distribution of emitted dust mass. The dashed line is the emitted dust in 192 prescribed bins in CanAM4. The solid line is a PLA distribution fitting to the parameterized dust emission, the two PLA size sections are for submicron $([0.1,1] \mu \mathrm{m})$ and supermicron $([1,10] \mu \mathrm{m})$, respectively.

The selection of size boundary and section width leads to a reasonable fit of PLA distribution to a global average of the emitted dust distribution (Fig. 2). With a climatological run of CanAM4, the annual global mean of emitted dust mass flux in 192 prescribed bins is shown in Fig. 2. Particles with radii larger than $10 \mu \mathrm{m}$ are omitted in the PLA distribution, because these particles will fall back to the surface quickly with gravitational settling. This is consistent with observed evidence (e.g., Arimoto et al., 1997) that most atmospheric dust particles are smaller than several microns, even near the source regions. However, on a few occasions, giant aerosols with radii larger than $50 \mu \mathrm{m}$ can be transported in the atmosphere. Considering that these giant particles have small direct radiative effects, we do not take them into account in this study.

\subsection{Dust transport and deposition}

For horizontal transport of mineral dust mass and number mixing ratios a spectral transform method is used, which is an extension of the hybrid variable transformation as described in Boer (1995). Unphysical negative values from spectral transport calculations are largely suppressed with the use of transformed variables (Merryfield et al., 2003), but the physical variable is not precisely conserved. A tracer mass correction method is therefore applied by assigning a scaling factor for simulated mass of each tracer. The magnitude of the mass correction is proportional to the net tracer tendency resulting from all physical parameterizations in each grid cell. 
The grid-cell mean continuity equation for dust in CanAM4-PAM is given by:

$$
\frac{\mathrm{d} X}{\mathrm{~d} t}=X_{\mathrm{E}}-X_{\mathrm{T}}-X_{\mathrm{D}}-X_{\mathrm{W}}
$$

where $X$ indicates the mass or number mixing ratio of dust aerosol in each of the PLA sections. $\frac{\mathrm{d} X}{\mathrm{~d} t}$ is the tendency of mass or number mixing ratio. $X_{\mathrm{E}}$ represents dust emission, $X_{\mathrm{T}}$ is the transport by advection and vertical diffusion, $X_{\mathrm{D}}$ refers to dry deposition together with the gravitational settling. $X_{\mathrm{W}}$ refers to wet deposition by stratiform and convective clouds. The PLA distribution is obtained from the advected aerosol mass and number mixing ratios for each size section at each time step according to Eqs. (1) and (2).

Dry deposition together with gravitational settling is important for dust removal near source regions on the continent. A size-dependent approach is used in this study. The dry deposition velocity is inversely proportional to a surface resistance, which is dependent on aerosol particle size as well as other properties of the surface and atmosphere (Zhang et al., 2001). The terminal velocity of gravitational settling is calculated as a function of aerosol particle radius, density as well as other related parameters, then integrated over each of the PLA sections (Ma et al., 2008). Gravitational settling is quite sensitive to the particle size. Large aerosols tend to have high terminal velocity thus fall down back to the surface very quickly.

Wet removal of aerosol by stratiform cloud includes rainout in clouds and washout by rain and snow below clouds. Dust aerosol is generally insoluble but can be mixed with other species such as sulfate, thus a certain fraction of dust particles are hygroscopic and can be activated to form cloud droplets (Sullivan et al., 2009). The in-cloud scavenging rate is proportional to the activated aerosol concentration, cloud fraction, and the sum of autoconversion rate and accretion rate, as well as inversely proportional to the cloud liquid water (Croft et al., 2005). The below-cloud scavenging rate is parameterized as a function of precipitation amount (rain and snow, respectively) according to Berge (1993).

Deep convection and shallow convective clouds are simulated in CanAM4-PAM as described by Zhang and McFarlane (1995) and von Salzen et al. (2005). Tracers transported by convective clouds are calculated according to von Salzen et al. (2000). The tracer removal rate is determined by upward and downward mass fluxes of air within the convective region, as well as the detrainment rate (Lohmann et al., 1999). For simplicity, wet deposition by convective clouds is not explicitly dependent on size in CanAM4-PAM.

\subsection{Parameterization of aerosol radiative properties}

Satellite observations provide an overview of the aerosol distribution, but usually do not provide information about the different aerosol components on a global scale. On a regional scale, remote sensing and satellite retrieval products are of- ten applied for dust aerosol studies. For example, Ginoux and Torres (2003) uses a Total Ozone Mapping Spectrometer (TOMS) aerosol index (AI) for a dust storm case over the North Atlantic and characterization of dust sources. Kaufman et al. (2005) uses aerosol data retrieved from MODIS for dust transport and deposition over the Atlantic Ocean. Peyridieu et al. (2010) uses the data from Atmospheric Infrared Sounder (AIRS) on board the NASA Aqua platform for Saharan dust over the North Atlantic. In addition, satellite retrievals of total aerosol are used to quantify the dust aerosol in and near source regions over the globe.

CanAM4-PAM simulates the radiative quantities for dust aerosol and for total aerosol, which can be validated with satellite measurements. Five major aerosol species including sulfate, black carbon (BC), organic carbon (OC), sea salt and mineral dust are considered in CanAM4-PAM. In this study, volcanic, biomass burning, aircraft, ship and other anthropogenic emissions are prescribed in each year for $\mathrm{BC}$ and $\mathrm{OC}$ aerosols and for $\mathrm{SO}_{2}$ (AeroCom_HC data as described in http://aerocom.met.no/emissions.html). Sea salt aerosol is simulated following Ma et al. (2008). Three PLA size sections are used for simulation of internally mixed sulfate, BC and OC aerosols. Sea salt and mineral dust aerosols are assumed externally mixed with two size sections for each.

Current radiative parameterization in CanAM4-PAM employs simple approximations of the aerosol size distribution. Dust aerosols are assumed in two size modes with mode radii of 0.39 and $1.9 \mu \mathrm{m}$, and standard deviation of 2.0 and 2.15 , respectively (Hess et al., 1998). Dust mass loading in two PLA sections are used in the two assumed modes for radiation calculation. About $20 \%$ of the mass of dust aerosols are attributed to the accumulation mode, which is consistent with other global model results from AeroCom (Textor et al., 2006).

Dust aerosol is regarded as primarily hydrophobic. Therefore water uptake is not considered in the radiation calculation. The specific extinction coefficient, single scattering albedo and asymmetry factor are functions of dust aerosol size distributions. These radiative parameters are calculated for the two assumed size modes by applying an off-line program based on Mie theory. Radiative properties such as the optical depth of aerosol extinction and absorption are obtained from the provided radiative parameters and aerosol mass at each model layer, and integrated vertically to obtain column values.

Relevant parameters for radiation calculation of five aerosol species in CanAM4-PAM are summarized in Table 1 . Sulfate and sea salt aerosols are simulated following Li et al. (2001) and Dobbie et al. (2003), respectively. $\mathrm{BC}$ and $\mathrm{OC}$ aerosols are parameterized as in Bäumer et al. (2007) in CanAM4-PAM. Hygroscopic growth of sulfate, sea salt and OC aerosols are limited to the relative humidity $(\mathrm{RH})$ below $95 \%$ in the radiation code, which is similar to other models (Reddy et al., 2005). As in most global climate models, an external mixture is assumed for calculation 
Table 1. Prescribed parameters of five major aerosols (sulfate, black carbon, organic carbon, sea salt and dust) for radiation calculations in CanAM4-PAM.

\begin{tabular}{llllll}
\hline & Sulfate & BC & OC & Sea salt & Dust \\
\hline$r_{\text {mode }}[\mu \mathrm{m}]$ & 0.05 & 0.032 & 0.032 & $0.05,1.75$ & $0.39,1.9$ \\
std. dev. & 2.0 & 2.0 & 2.0 & $2.03,2.03$ & $2.0,2.15$ \\
hygroscopicity & hydrophilic & hydrophobic & hydrophilic & hydrophilic & hydrophobic \\
threshold $\mathrm{RH}$ & $95 \%$ & n/a & $95 \%$ & $95 \%$ & n/a \\
\hline
\end{tabular}

Table 2. Run types, selected time period and wind tuning parameter $\left(C_{u}\right)$ for simulations comparing with different observed datasets in Sects. 3 and 4.

\begin{tabular}{|c|c|c|c|c|c|}
\hline Sect. & Observed Dataset & Focused Variable & Run Type & Selected Period & $C_{u}$ \\
\hline 3.1 & Case study in Beijing & aerosol number-size spectra & Nudged & 2004-2005 & 0.75 \\
\hline 3.2 & AERONET Inversion data & aerosol volume-size spectra & Climate & $5 \mathrm{yr}$ & 0.85 \\
\hline 3.3 & Station data in Asia & dust surface concentration & Nudged & $2000-2001$ & 0.75 \\
\hline 3.4 & Extended Univ. of Miami data & dust surface concentration & Climate & $5 \mathrm{yr}$ & 0.85 \\
\hline 3.5 & Compiled deposition data & dust deposition rate & Climate & $5 \mathrm{yr}$ & 0.85 \\
\hline 4.1 & MODIS, MISR and combined data & aerosol optical depth & Nudged & 2001-2006 & 0.75 \\
\hline 4.2 & AERONET & aerosol optical depth & Nudged & 2001-2006 & 0.75 \\
\hline 4.3 & MODIS/CERES & aerosol direct radiative forcing & Nudged & 2001 & 0.75 \\
\hline
\end{tabular}

of radiative properties. The effect of internally mixing with sulfate, BC and OC aerosols on the radiative properties are not included in the current radiation calculation in CanAM4PAM. Aerosol optical depth at a wavelength of $0.55 \mu \mathrm{m}$ is diagnosed for dust and the total aerosol, which will be used to compare with satellite observational data in Sect. 4.

In CanAM4-PAM, a correlated k-distribution scheme is used for the radiative flux calculation (Li and Barker, 2005). The aerosol direct radiative forcing (ADRF) is determined as the difference in net radiative fluxes at the top of atmosphere (TOA) due to scattering and absorption of radiation by aerosol, which is often investigated to quantify the radiative impact of aerosols on the climate. The radiation code is called twice to diagnose the change in net radiative fluxes at TOA that is associated with a change in aerosol concentrations in the model, leaving temperature and other variables constant (Forster et al., 2007). This approach can be applied for each aerosol component in order to estimate the ADRF of dust aerosol, as well as for the total aerosol.

It should be pointed out that radiative parameters applied in this study (Hess et al., 1998) possibly overestimate the absorption of mineral dust, which could contribute to the discrepancies in both sign and magnitude of the estimated dust ADRF (Balkanski et al., 2007). A correction of prescribed dust refractive indices according to satellite and ground-based remote sensing data may lead to a more realistic estimation of ADRF (e.g., Kaufman et al., 2001; Moulin et al., 2001). Improvements of dust radiative parameters in the model require more detailed information about the dust aerosol size distribution, mineralogical composition and the mixing state with anthropogenic aerosols, which will be left for a future study.

\subsection{Run information and parameter sensitivities}

Two types of model simulations are considered for this study. One is a climate run, which is driven with climatological sea surface temperatures (SST), while the other uses nudging of model temperature, vorticity and divergence to ERA40 reanalysis data (Merryfield et al., 2011). As mentioned in Sect. 2.1, dust emissions are very sensitive to changes in model simulated wind speed $\left(U^{*}\right)$. The nudging run applies a relaxation technique so that the analyzed meteorology forces the evolution of dust, in order to minimize the effects of biases in simulated wind fields on dust emissions.

The climate run is performed for five years (1991-1995) after a one year spin-up, driven by the climatology SST from AMIP (Atmospheric Model Intercomparison Project) for the period 1979 to 1995 . The nudged run is from year 2000 to 2006, with two months spin-up. Nudging is applied to both temperature and wind fields and the relaxation time is $6 \mathrm{~h}$.

Table 2 summarizes the run types and selected time period for comparison with different observed datasets in Sects. 3 and 4. For AERONET Inversion data used in Sect. 3.2, Extended Univ. of Miami data in Sect. 3.4 and compiled deposition data used in Sect. 3.5, they are derived from multiple-year measurements and regarded as climatological representatives. Thus model results of the climate run with CanAM4-PAM are taken for comparisons. For other observed datasets with specified time period, CanAM4-PAM 
results from nudged run are taken for model-observation comparisons.

The threshold wind friction velocity is subject to considerable uncertainty. A tunable parameter $\left(C_{u}\right)$ is used in CanAM4-PAM to scale the threshold wind friction velocity in order to obtain a global annual mean emission amount within a range of current estimates. This parameter has a weak effect on the spatial and temporal distribution of dust aerosol (e.g., Timmreck and Schulz, 2004; Cheng et al., 2008). In this study, $C_{u}$ is 0.85 for the climate run and 0.75 for the nudging run (see Table 2).

The probability for the friction velocity to exceed the threshold velocity increases with decreasing value of the scaling parameter $C_{u}$, which leads to increasing dust emissions. For given parameter settings, changes in the scaling parameter by \pm 0.05 lead to changes in dust burden by approximately $\mp 20 \%$.

Another important, but uncertain parameter for dust emission is the surface roughness length. As mentioned in Sect. 2.1, dust emission and mass burden decrease with increasing surface roughness. By altering the surface roughness length by $\pm 50 \%$ globally, the annual dust mass burden is changed by around $30 \%$.

The sensitivity of dust amount to the soil moisture is relatively weak. Dust emission and mass burden vary nonlinearly with the input fraction of soil composition and prescribed soil particle size distributions (Marticorena and Bergametti, 1995; Marticorena et al., 1997).

\section{Validation with surface measurements}

Table 3 summarizes the annual global dust emission amount and mass load of CanAM4-PAM runs, in comparison with results from other recent studies. Both emission and mass burden of dust are within the estimated range. However, the range of current model estimates is large. This gives evidence for considerable uncertainties in simulations of mineral dust and indicates substantial need for model validation efforts. In this section, various surface measurement datasets are compared with model results (see Table 2). Simulated optical depth and radiative forcing of dust are also validated with satellite retrieved data in Sect. 4.

\subsection{Case study in Beijing}

One recent case with continuous measurements of aerosol number size distribution is available in the city of Beijing, China, from March 2004 to February 2005. Beijing is located southeast of the main Asian desert areas such as the Gobi and Mongolia. Dust storms prevail in spring and dust aerosols transported from those remote sources dominate in the coarse mode at all time (Seinfeld et al., 2004). Other important aerosol species in this region include sulfate and organic compounds, which are mostly attributed to local sources such as fossil fuel combustion for heating, lateral industry pollution and vehicle emissions in the city area (Wehner et al., 2008).

The sampling site is at Peking University, which is in the northwest of the city. Instruments including two particle counters (TSI3010 and TSI3025) and an APS (Aerodynamic Particle Sizer) were located on a six-floor building, at a height of $20 \mathrm{~m}$ above the ground (Wehner et al., 2004). Dry aerosol particles with diameter of 0.003 to $10 \mu \mathrm{m}$ were collected every ten minutes. Data was post-processed (Wehner et al., 2004) and further averaged to obtain monthly means. Measurements with records in more than 20 days of each month are selected to calculate the monthly averages.

CanAM4-PAM is run with nudging from January 2004 to the end of February 2005. Results from the model simulation are selected at the corresponding times when observations are available. The total aerosol number size distribution at the lowest model layer is averaged over each month and compared with measurements as shown in Fig. 3. In most of the cases, the observed and simulated size distributions are clearly divided into submicron and supermicron modes as indicated by a dashed line at a radius of $0.5 \mu \mathrm{m}$ (e.g., diameter of $1 \mu \mathrm{m}$ ) in Fig. 3. According to Wehner et al. (2008), local traffic and industrial pollutants are responsible for most of the emissions of submicron aerosols. New particle formation is specifically important for nucleation mode aerosols (Yue et al., 2009). Growth of nucleation mode particles through condensation and coagulation of pollutants leads to increases in Aitken and accumulation mode particles. Aside from desert dust transported over long distances, local construction and road dust contributes to coarse mode particles, too (Wehner et al., 2008; Yue et al., 2009). However, desert dust from non-local sources dominates the concentration of supermicron aerosol.

For all cases shown in Fig. 3, concentration of submicron particles are underestimated by the model. Highly polluted conditions in urban plumes occur on spatial scales that are not resolved by the model. Therefore, concentrations of submicron particles are underestimated in Fig. 3. It is also possible that model underestimates the dust contribution to the submicron because the model resolution is too coarse to simulate road dust from local traffic.

On the other hand, modelled size distributions of supermicron particles generally agree well with measurements in Fig. 3. For January and February, coarse mode aerosols are underestimated. Since the local wind is strong in Beijing during winter, large particles generated from urban construction and road traffic likely contribute to the observations, which are not included in the global model. Thus differences between model and measurements are more evident in the coarse mode during this season.

In July and August, during the rainy season in Beijing, heavy precipitation leads to efficient wet deposition, which washes out fine to medium size particles and reshapes the number size distribution of aerosols (Yue et al., 2009). 
Table 3. Summary of annual global dust emission, mass load, AOD at $0.55 \mu \mathrm{m}$ and shortwave ADRF at TOA from CanAM4-PAM and from other recent studies.

\begin{tabular}{|c|c|c|c|c|c|}
\hline & CanAM4-PAM & & Other Studies & & \\
\hline & Run Type & Results & Source & Estimates & Reference \\
\hline \multicolumn{6}{|l|}{$\begin{array}{l}\text { Emission } \\
\left(\mathrm{Tg} \mathrm{yr}^{-1}\right)\end{array}$} \\
\hline & $\begin{array}{l}\text { Climate } \\
\text { Nudged } \\
(\text { yr 2000) }\end{array}$ & $\begin{array}{l}2700 \\
2500\end{array}$ & $\begin{array}{l}\text { Multiple models } \\
\text { AeroCom Phase I models (ExpA) } \\
\text { Global OBS datasets \& GISS model } \\
\text { AeroCom Phase I models }\end{array}$ & $\begin{array}{l}1000 \sim 3000 \\
800 \sim 2500 \\
1500 \sim 2600 \\
500 \sim 4300\end{array}$ & $\begin{array}{l}\text { Zender et al. (2004) } \\
\text { Textor et al. (2006) } \\
\text { Cakmur et al. (2006) } \\
\text { Huneeus et al. (2011) }\end{array}$ \\
\hline \multicolumn{6}{|l|}{$\begin{array}{l}\text { Mass load } \\
(\mathrm{Tg})\end{array}$} \\
\hline & $\begin{array}{l}\text { Climate } \\
\text { Nudged } \\
(\mathrm{yr} 2000)\end{array}$ & $\begin{array}{l}21.0 \\
19.3\end{array}$ & $\begin{array}{l}\text { Multiple models } \\
\text { AeroCom Phase I models (ExpA) } \\
\text { AeroCom Phase I models (ExpB) } \\
\text { CTM coupled with GCM } \\
\text { CSIRO Mk3.6 GCM }\end{array}$ & $\begin{array}{l}8 \sim 36 \\
22.7 \pm 21 \\
21.3 \pm 21 \\
14.6 \\
35\end{array}$ & $\begin{array}{l}\text { Zender et al. (2004) } \\
\text { Textor et al. (2007) } \\
\text { Textor et al. (2007) } \\
\text { Tanaka and Chiba (2006) } \\
\text { Rotstayn et al. (2011) }\end{array}$ \\
\hline \multicolumn{6}{|l|}{ AOD } \\
\hline & $\begin{array}{l}\text { Nudged } \\
(\mathrm{yr} 2000)\end{array}$ & 0.042 & AeroCom Phase I models (ExpA) & $\begin{array}{l}0.009 \sim 0.054 \\
0.032(\text { median })\end{array}$ & Kinne et al. (2006) \\
\hline & $\begin{array}{l}\text { Nudged } \\
(2001-2006)\end{array}$ & 0.034 & $\begin{array}{l}\text { NASA GISS ModelE AGCM } \\
\text { Oslo CTM2 } \\
\text { AeroCom Phase I models }\end{array}$ & $\begin{array}{l}0.028 \\
0.024 \\
0.01 \sim 0.053 \\
0.023 \text { (median) }\end{array}$ & $\begin{array}{l}\text { Miller et al. (2006) } \\
\text { Myhre et al. (2007) } \\
\text { Huneeus et al. (2011) }\end{array}$ \\
\hline & & & $\begin{array}{l}\text { CERES/MODIS retrieval } \\
\& \text { GOCART model }\end{array}$ & 0.04 & Zhao et al. (2010) \\
\hline \multicolumn{6}{|l|}{$\begin{array}{l}\mathrm{ADRF} \\
\left(\mathrm{W} \mathrm{m}^{-2}\right)\end{array}$} \\
\hline & $\begin{array}{l}\text { Nudged } \\
(\text { yr 2001) }\end{array}$ & -1.24 & $\begin{array}{l}\text { Multiple models } \\
\text { 20th century estimates from } \\
\text { paleodata proxy } \\
\text { CERES/MODIS retrieval } \\
\text { \& GOCART model }\end{array}$ & $\begin{array}{l}-1.4 \sim+0.2 \\
-0.69 \sim-0.36 \\
-0.5(\mathrm{avg}) \\
-1.6 \pm 0.5\end{array}$ & $\begin{array}{l}\text { Solomon et al. (2007) } \\
\text { Mahowald et al. (2010) } \\
\text { Zhao et al. (2010) }\end{array}$ \\
\hline
\end{tabular}

Therefore the bi-modal distribution pattern is not as evident as in other months.

In summary, CanAM4-PAM is able to capture the bimodal nature of the aerosol size distribution. Model results are consistent with direct measurements of aerosol at the surface, and agree well in the coarse mode where dust particles dominate. However, underestimation of submicron dust aerosol can not be ruled out.

\subsection{AERONET inversion data}

The global network AERONET (Aerosol Robotic Network) collects ground-based remote sensing data and provides a long-term continuous dataset of aerosol optical and microphysical properties (Holben et al., 1998, 2001). Sun photometers at AERONET sites measure the solar radiances. Only daytime and clear sky conditions are considered. An in- version algorithm is applied to retrieve a set of aerosol properties (Dubovik and King, 2000), including the volume-size distribution of aerosol particles between 0.05 and $15 \mu \mathrm{m}$.

Since this study focuses on dust aerosol, we extract data from the "dusty" sites in AERONET as defined in Huneeus et al. (2011), where the observed monthly mean total AOD is larger than 0.2 and monthly averaged AE (Angstrom Exponent) is smaller than 0.4 for at least two months in a year. During the time period 1996-2006, twenty-five AERONET sites are considered "dusty" according to this criterion. They are divided into four groups as shown in Fig. 4. The site names and locations are listed in Table 4.

A vertically integrated aerosol volume-size distribution is diagnosed in CanAM4-PAM from the 5-yr climate run and compared with the AERONET inversion data at the "dusty" sites. Figure 5 indicates that the model generally 

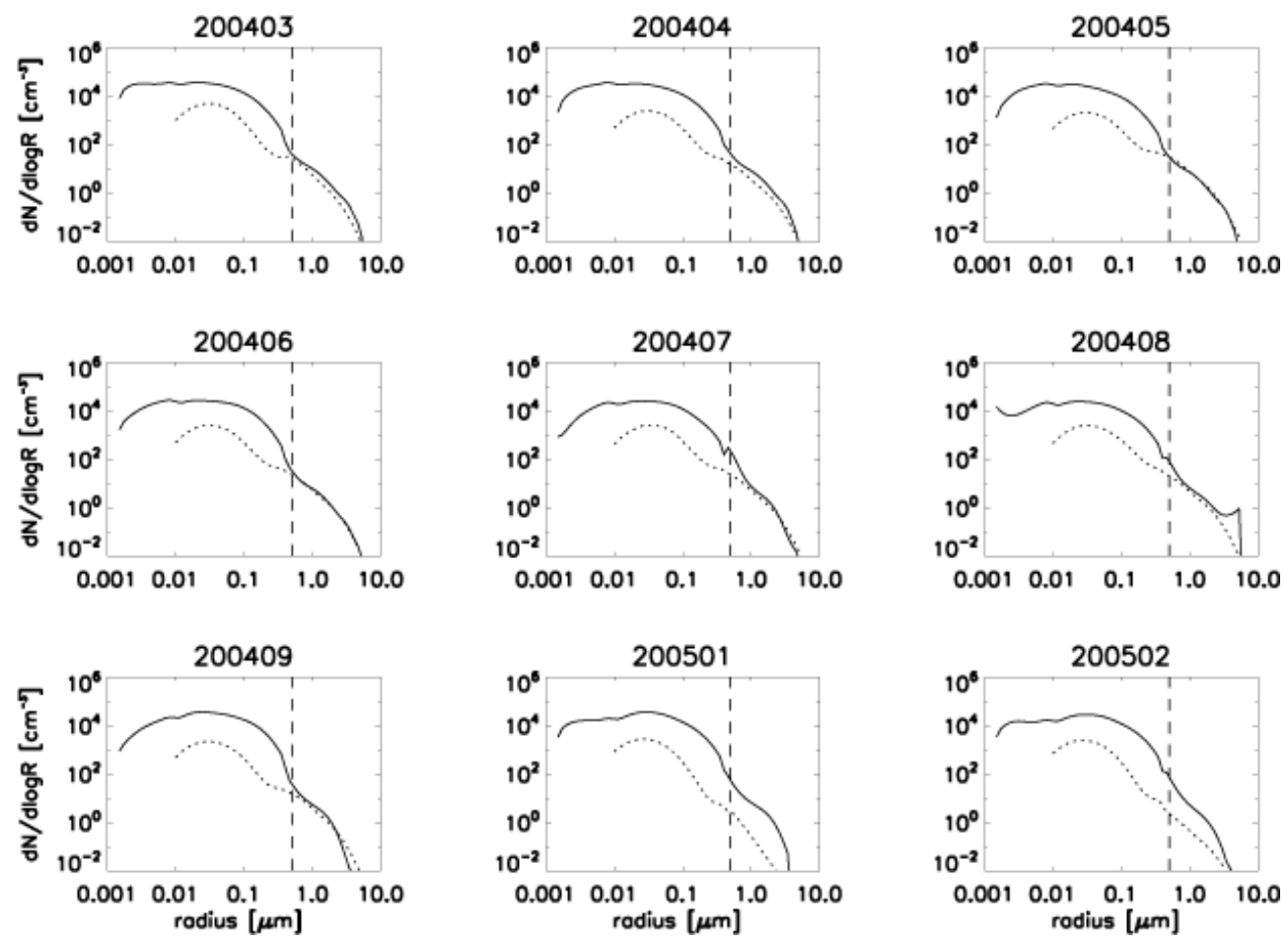

Fig. 3. Aerosol number size distribution in Beijing from March 2004 to February 2005. The solid line refers to the observations and the dotted line to the model results. The vertical dashed line is a separation between submicron and supermicron modes. Data in the last three months of year 2004 are too sparse to be included.

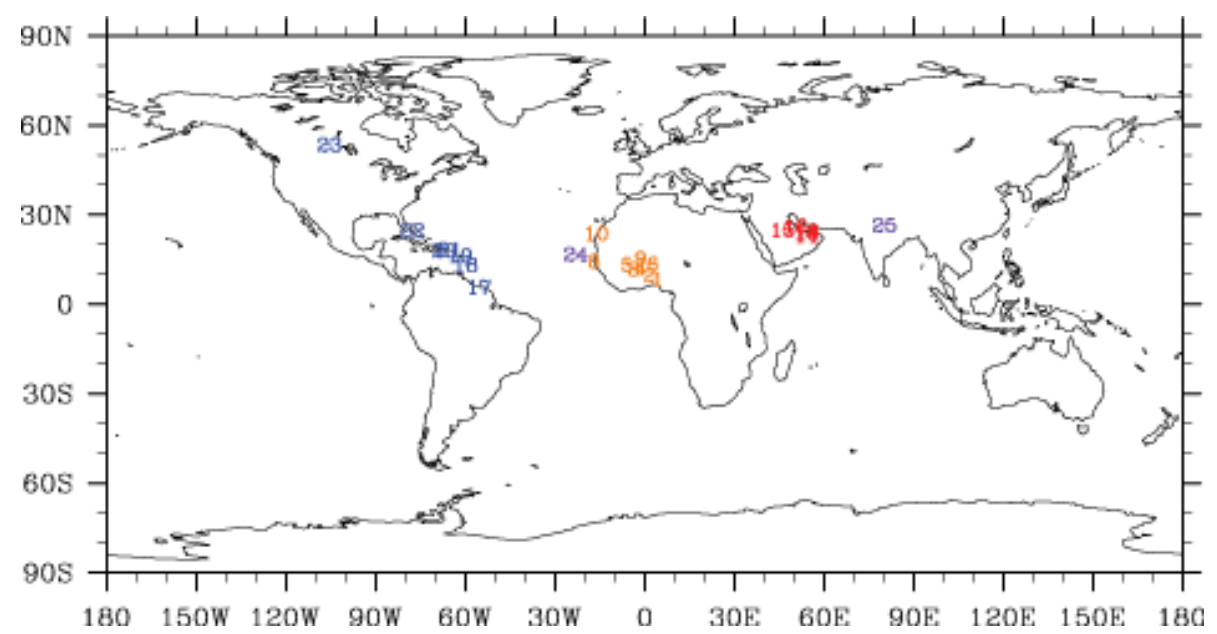

Fig. 4. Location of "dusty" sites selected from AERONET according to the data in years 1996-2006. Sites are divided into four groups: Middle East (red), Africa (orange), Caribbean-America (blue) and elsewhere in the world (purple). Name, latitude and longitude of each site are listed in Table 4.

underestimates concentrations of small particles at around $0.1 \mu \mathrm{m}$ and overestimates at supermicron sizes. The overestimation in large size particles are evident at all Middle Eastern sites (11 to 16) and at several West African sites (5 to 10 and 24). These two regions are major dust sources and the comparison indicates that the PLA emission scheme has limitations in reproducing the dust size distribution. Based on ob- servations at "dusty" sites, sources in West Africa emit more large particles than Middle Eastern and Asian sources. This feature is hardly captured by the model. More detailed soil population data and surface information in different source regions may help to increase the accuracy of the simulated emissions. 
Table 4. "Dusty" sites selected from AERONET according to the data in years 1996-2006. Sites are divided into four groups based on the location. $N$ is the number of each site as shown in Fig. 4.

\begin{tabular}{lllll}
\hline$N$ & Site & Lat & Lon & Region \\
\hline 1 & Ilorin & $8.32^{\circ} \mathrm{N}$ & $4.34^{\circ} \mathrm{E}$ & Africa \\
2 & Djougou & $9.76^{\circ} \mathrm{N}$ & $1.60^{\circ} \mathrm{E}$ & Africa \\
3 & Bondoukoui & $11.85^{\circ} \mathrm{N}$ & $3.75^{\circ} \mathrm{W}$ & Africa \\
4 & Ouagadougou & $12.20^{\circ} \mathrm{N}$ & $1.40^{\circ} \mathrm{W}$ & Africa \\
5 & IER Cinzana & $13.28^{\circ} \mathrm{N}$ & $5.93^{\circ} \mathrm{W}$ & Africa \\
6 & Banizoumbou & $13.54^{\circ} \mathrm{N}$ & $2.67^{\circ} \mathrm{E}$ & Africa \\
7 & Bidi Bahn & $14.06^{\circ} \mathrm{N}$ & $2.45^{\circ} \mathrm{W}$ & Africa \\
8 & Dakar & $14.39^{\circ} \mathrm{N}$ & $16.96^{\circ} \mathrm{W}$ & Africa \\
9 & Agoufou & $15.35^{\circ} \mathrm{N}$ & $1.48^{\circ} \mathrm{W}$ & Africa \\
10 & Dahkla & $23.72^{\circ} \mathrm{N}$ & $15.95^{\circ} \mathrm{W}$ & Africa \\
\hline 11 & Hamim & $22.97^{\circ} \mathrm{N}$ & $54.30^{\circ} \mathrm{E}$ & Middle East \\
12 & Al Dhafra & $24.25^{\circ} \mathrm{N}$ & $54.55^{\circ} \mathrm{E}$ & Middle East \\
13 & Mussafa & $24.37^{\circ} \mathrm{N}$ & $54.47^{\circ} \mathrm{E}$ & Middle East \\
14 & Dhabi & $24.48^{\circ} \mathrm{N}$ & $54.38^{\circ} \mathrm{E}$ & Middle East \\
15 & Solar Village & $24.91^{\circ} \mathrm{N}$ & $46.40^{\circ} \mathrm{E}$ & Middle East \\
16 & Bahrain & $26.21^{\circ} \mathrm{N}$ & $50.61^{\circ} \mathrm{E}$ & Middle East \\
\hline 17 & Surinam & $5.80^{\circ} \mathrm{N}$ & $55.20^{\circ} \mathrm{W}$ & Caribbean-America \\
18 & Barbados & $13.15^{\circ} \mathrm{N}$ & $59.62^{\circ} \mathrm{W}$ & Caribbean-America \\
19 & Guadeloup & $16.33^{\circ} \mathrm{N}$ & $61.50^{\circ} \mathrm{W}$ & Caribbean-America \\
20 & La Parguera & $17.97^{\circ} \mathrm{N}$ & $67.05^{\circ} \mathrm{W}$ & Caribbean-America \\
21 & Cape San Juan & $18.38^{\circ} \mathrm{N}$ & $65.62^{\circ} \mathrm{W}$ & Caribbean-America \\
22 & Andros Island & $24.70^{\circ} \mathrm{N}$ & $77.80^{\circ} \mathrm{W}$ & Caribbean-America \\
23 & Paddockwood & $53.50^{\circ} \mathrm{N}$ & $105.50^{\circ} \mathrm{W}$ & Caribbean-America \\
\hline 24 & Capo Verde & $16.73^{\circ} \mathrm{N}$ & $22.94^{\circ} \mathrm{W}$ & Elsewhere \\
25 & Kanpur & $26.51^{\circ} \mathrm{N}$ & $80.23^{\circ} \mathrm{E}$ & Elsewhere \\
\hline & & &
\end{tabular}

The coarse mode aerosol around $10 \mu \mathrm{m}$ is overestimated at Caribbean-American sites (17 to 21), where dust aerosols are mostly transported from Saharan desert. This is possibly due to an excessive transport or weak deposition (which is further discussed in Sects. 3.4 and 3.5) in the model. For North America (site 23) and India (site 25), the model overestimates concentrations of particles around $1 \mu \mathrm{m}$. Dust aerosols at these two sites are not attributed to any major global sources. We think that local emissions are responsible for the dust occurrence. The model may not be able to sufficiently reproduce these local sources.

Overall CanAM4-PAM can reproduce the size distributions of dust aerosols near and away from major dusty areas. However, model emission scheme has difficulties in capturing details at different dust source regions. In general the model tends to underestimate the fine mode and overestimate the coarse mode dust aerosol concentrations.

\subsection{Surface concentrations in Asia}

Global model estimates of dust aerosol are generally uncertain in Asia with few observations available that can be used to validate model. In this subsection a Asian dataset provides useful constraints for dust simulated with CanAM4-PAM.

Dust aerosol mass concentrations near the surface can be estimated from visibility measurements during dust episodes by following an empirical relationship (Shao et al., 2003). Based on regular weather station records, visibility data were collected at 16 stations over Northeast Asia, which covers the Taklamakan Desert, Gobi and some coastal regions influenced by the Asian dust plume. Locations of measurement stations are listed in Table 5 and shown in Fig. 6. Data are selected during the main dust season (spring in Asia), and those taken during the rest of the time period are removed in order to eliminate the impact of other aerosol species. Measurements of surface dust concentrations are averaged over March, April and May (MAM) of year 2000 and 2001 (Cheng et al., 2008).

CanAM4-PAM is run with nudging for years 2000 and 2001. Simulated dust concentrations at the surface are compared with observations in Fig. 7. The gradients from the source regions (deserts in Northwest China) to the distant ocean are well captured by the model. There are no clear systematic differences between the model and observations for any of the sites.

\subsection{Surface concentrations at marine sites}

Long-term measurements of surface dust mass concentrations are available from the network experiments managed by University of Miami (Prospero, 1999; Arimoto et al., 1995). Data were collected at 20 remote marine sites and have various time period lasting from 1980s to 1990s. The dust mass concentration is derived from observed aluminum concentrations by assuming $8 \%$ of aluminum content in mineral dust aerosols (Prospero, 1999). Measured data are averaged over multiple years to obtain an annual mean and 12 monthly means. This dataset has been widely used for evaluating the model performances (e.g., Ginoux et al., 2001; Tegen et al., 2002; Solomon et al., 2007).

The University of Miami dataset is extended with two additional measurements at Rukomechi, Zimbabwe (Nyanganyura et al., 2007) and at Jabiru, Australia (Vanderzalm et al., 2003). Both annual mean and monthly means of dust surface concentration are available at these sites. The dataset was first compiled and applied for model evaluation in Huneeus et al. (2011). We follow their procedure to divide the sites into three groups according to the magnitude of dust surface concentration as shown in Fig. 8. Remote sites in the Antarctic and in the Equatorial and South Pacific Oceans are far from any dust sources thus have relatively low dust surface concentrations (orange in Figs. 8 and 9). Sites influenced by dust sources have medium surface concentration, such as sites in the North Pacific Ocean within the Asian dust plume and sites around Australia (red in Figs. 8 and 9). Sites downwind of major dust sources in Africa and Asia are characterized by high values of the dust surface concentration (blue in Figs. 8 and 9). Name, latitude and longitude of each site are listed in Table 6.

For this comparison, CanAM4-PAM results are taken from the climate run. Simulated dust aerosol concentrations are 

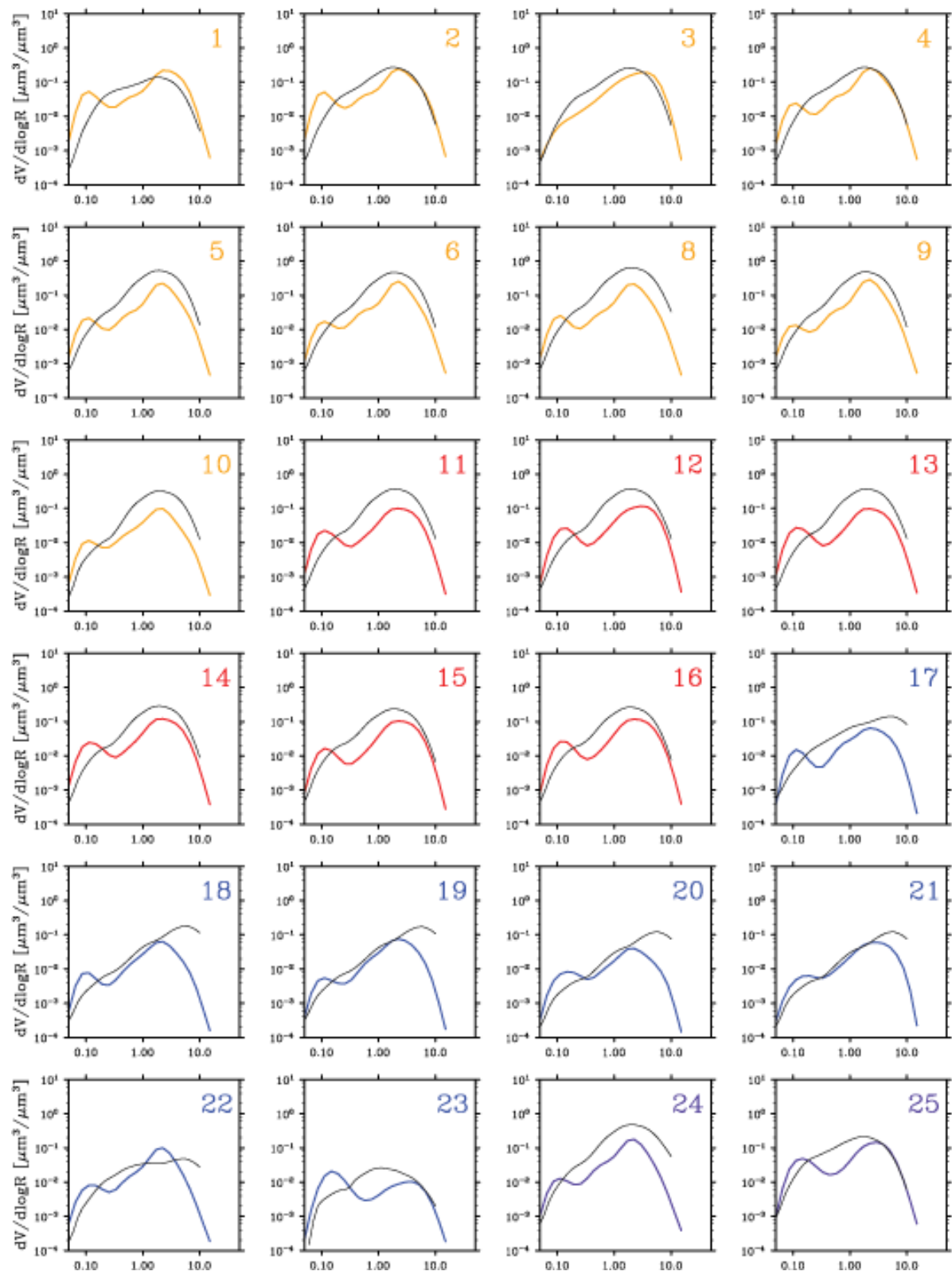

Fig. 5. Comparison of aerosol volume-size distribution at "dusty" sites. Color curves are from AERONET inversion retrieval data. Black curves are results from the climate run of CanAM4-PAM at each site. Color and number are corresponding to the regional groups as in Fig. 4: Middle East (red), Africa (orange), Caribbean-America (blue) and elsewhere in the world (purple). Names and locations of sites are listed in Table 4. Site 7 is not shown because of the lack of inversion retrieval in this location. The abscissa corresponds to the aerosol particle radius in $\mu \mathrm{m}$.

extracted from the grid points corresponding to the locations of the observation. Annual means of simulated dust mass concentrations are compared with the measurements in Fig. 9. When dust concentration is high, that is, near source regions, model results align well with the $1: 1$ line, although the concentrations are slightly underestimated. A likely reason for the underestimation is local dust sources that are not resolved by the GCM.
When dust concentration is low, that is, far from source regions, the model tends to overestimate the concentrations. This may be explained by insufficient deposition near source regions, which leads to an excessive transport of aerosols to remote areas. There is some support for this hypothesis from results for deposition fluxes in Sect. 3.5.

Results in Fig. 9 agree well with results shown in Fig. 5 of Huneeus et al. (2011). However, note that results in Huneeus et al. (2011) are for year 2000 whereas climatological results 
Table 5. Asian stations to derive the dust surface concentration from visibility in spring of 2000 and 2001. Stations are divided into three groups according to the country. $N$ is the number of each station as shown in Fig. 6.

\begin{tabular}{lllll}
\hline$N$ & Station & Lat & Lon & Country \\
\hline 1 & Aksu & $40.27^{\circ} \mathrm{N}$ & $80.47^{\circ} \mathrm{E}$ & China \\
2 & Dunhuang & $40.50^{\circ} \mathrm{N}$ & $94.82^{\circ} \mathrm{E}$ & China \\
3 & Zhenbeitai & $38.29^{\circ} \mathrm{N}$ & $109.70^{\circ} \mathrm{E}$ & China \\
4 & Changwu & $35.02^{\circ} \mathrm{N}$ & $107.68^{\circ} \mathrm{E}$ & China \\
5 & Lanzhou & $36.05^{\circ} \mathrm{N}$ & $103.88^{\circ} \mathrm{E}$ & China \\
6 & Shapotou & $37.50^{\circ} \mathrm{N}$ & $105.00^{\circ} \mathrm{E}$ & China \\
7 & Inner Mongolia & $42.67^{\circ} \mathrm{N}$ & $115.95^{\circ} \mathrm{E}$ & China \\
8 & Beijing & $39.93^{\circ} \mathrm{N}$ & $116.35^{\circ} \mathrm{E}$ & China \\
9 & Qingdao & $36.07^{\circ} \mathrm{N}$ & $120.33^{\circ} \mathrm{E}$ & China \\
10 & Hefei & $31.90^{\circ} \mathrm{N}$ & $117.16^{\circ} \mathrm{E}$ & China \\
\hline 11 & Seoul & $37.53^{\circ} \mathrm{N}$ & $127.07^{\circ} \mathrm{E}$ & South Korea \\
12 & Gosan & $33.29^{\circ} \mathrm{N}$ & $126.16^{\circ} \mathrm{E}$ & South Korea \\
\hline 13 & Tsukuba & $36.06^{\circ} \mathrm{N}$ & $140.14^{\circ} \mathrm{E}$ & Japan \\
14 & Nagoya & $35.15^{\circ} \mathrm{N}$ & $136.96^{\circ} \mathrm{E}$ & Japan \\
15 & Fukuoka & $33.55^{\circ} \mathrm{N}$ & $130.37^{\circ} \mathrm{E}$ & Japan \\
16 & Naha & $26.20^{\circ} \mathrm{N}$ & $127.69^{\circ} \mathrm{E}$ & Japan \\
\hline
\end{tabular}

are used from CanAM4-PAM. According to Huneeus et al. (2011), biases of $14 \mathrm{GCM}$ results to the observation are between -1.96 and 2.52 (by excluding the extremes of minimum and maximum values. Same for all the ranges from Huneeus et al. (2011) in the following text). The bias of CanAM4-PAM is within this range (-0.99). CanAM4-PAM produces a slightly better correlation between model and observed surface concentrations than most models (i.e., 0.90 compared to the range of 0.62 to 0.87 reported by Huneeus et al., 2011).

A comparison of monthly mean dust surface concentrations is shown in Fig. 10. Observed dust surface concentrations and biases of modeled to observed data are also plotted in Fig. 11. Model results show an overall good agreement with observations downwind of source regions (sites 17 to 22) and at those sites under influence of dust sources (sites 8 to 16), but overestimate at all remotes sites (sites 1 to 7 ).

At the source site downwind of a local desert in South Africa (17, Rukomechi in Zimbabwe), the model underestimates dust concentrations most time of the year. It is not surprising as all models in Huneeus et al. (2011) behave similarly at this location.

Three sites in Central America (18, 19 and 21, Barbados, Miami and Bermuda) are strongly affected by the Saharan dust plume in summer. The model results show good consistency at these sites when dust peaks from June to September (Fig. 10), but simulated dust concentrations are slightly underestimated, which is in opposite to most models in Huneeus et al. (2011). This can be attributed to an inefficient cross-Atlantic transport or too strong local deposi-

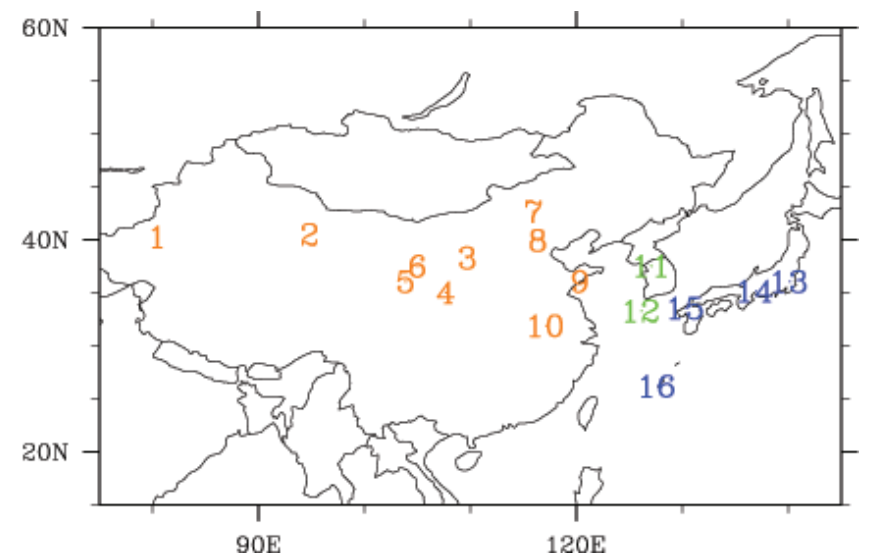

Fig. 6. Location of Asian stations to derive the dust surface concentration from visibility in spring of 2000 and 2001. Stations are divided into three groups according to the country: China (orange), South Korea (green) and Japan (blue). Name, latitude and longitude of each station are listed in Table 5.

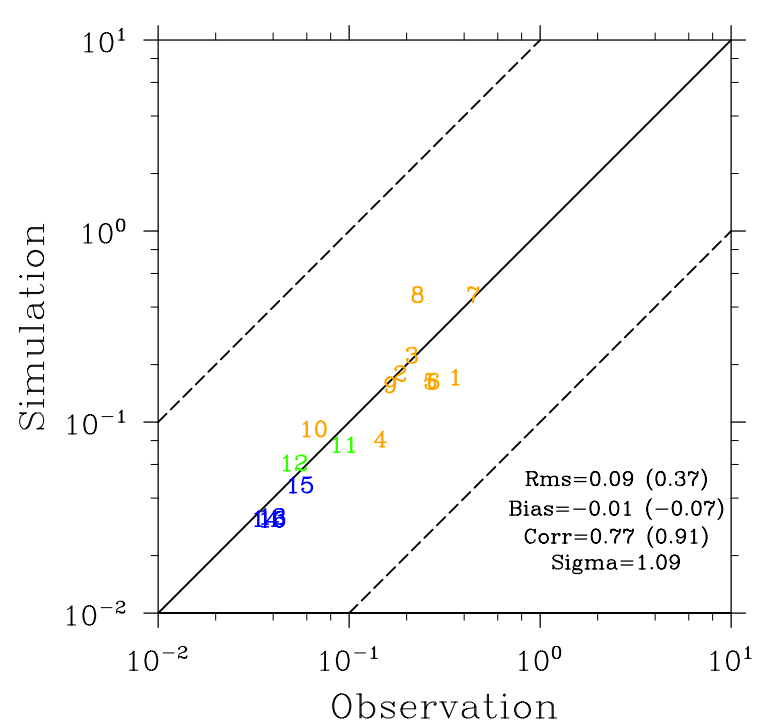

Fig. 7. Comparison of surface dust concentration $\left(\mathrm{mg} \mathrm{m}^{-3}\right)$ between CanAM4-PAM simulation and visibility-based estimates from measurements in Asia. Model results are averaged over MAM in 2000 and 2001. Stations are grouped according to the country as shown in Fig. 6: China (orange), South Korea (green) and Japan (blue). Locations of each station are listed in Table 5. Root mean square error (Rms), bias, correlation (Corr) and ratio of modelled to observed standard deviation (sigma) are indicated. Normalized root mean square error and mean normalized bias are given in the parenthesis next to Rms and Bias. The correlation with respect to the logarithm of the model results and of the observation is given in the parenthesis next to Corr. Black solid line is the $1: 1$ line and black dash lines are $10: 1$ and $1: 10$ lines.

tion. We investigate the wet deposition and total deposition by comparing with 3-yr averaged seasonal data observed by the FAMS (Florida Atmospheric Mercury Study) network at 


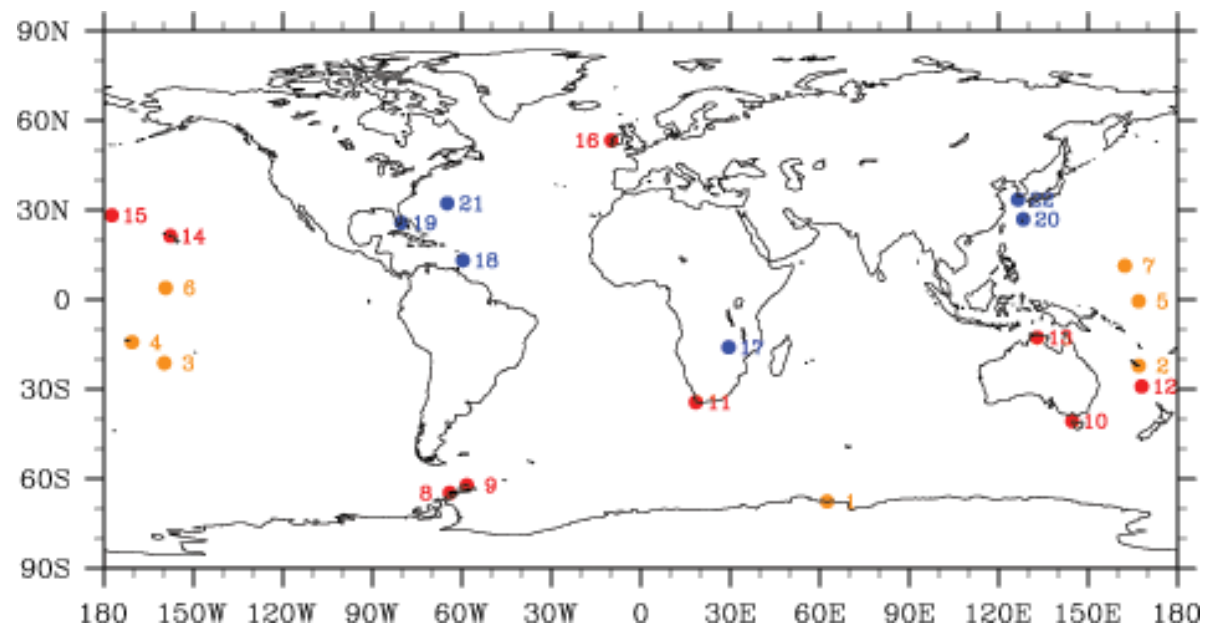

Fig. 8. Location of sites from the extended University of Miami dataset for annual and monthly mean dust surface concentration measurements. Sites are divided into three groups according to the magnitude of the data and distances from the dust sources: remote sites with low dust surface concentration (orange), sites under the influence of dust sources and with medium concentrations (red), and sites downwind the major dust sources in Africa and Asia and with high concentrations (blue). Name, latitude and longitude of each site are listed in Table 6.

Table 6. Sites from the extended University of Miami dataset for climatological dust surface concentration measurements. Sites are divided into three groups according to the magnitude of data and distances from the dust sources. $N$ is the number of each site as shown in Fig. 8 . The asterisks mark the sites in addition to the University of Miami dataset.

\begin{tabular}{llllll}
\hline$N$ & Site & Lat & Lon & Location & Data Range \\
\hline 1 & Mawson & $67.60^{\circ} \mathrm{S}$ & $62.50^{\circ} \mathrm{E}$ & Antarctica & Low \\
2 & New Caledonia & $22.15^{\circ} \mathrm{S}$ & $167.00^{\circ} \mathrm{E}$ & S.W. Pacific & Low \\
3 & Cook Islands & $21.25^{\circ} \mathrm{S}$ & $159.75^{\circ} \mathrm{W}$ & S. Pacific & Low \\
4 & American Samoa & $14.25^{\circ} \mathrm{S}$ & $170.58^{\circ} \mathrm{W}$ & S. Pacific & Low \\
5 & Nauru & $0.53^{\circ} \mathrm{S}$ & $166.95^{\circ} \mathrm{E}$ & Equ. Pacific & Low \\
6 & Fanning Island & $3.92^{\circ} \mathrm{N}$ & $159.33^{\circ} \mathrm{W}$ & Equ. Pacific & Low \\
7 & Enewetak Atoll & $11.33^{\circ} \mathrm{N}$ & $162.33^{\circ} \mathrm{E}$ & W. Pacific & Low \\
\hline 8 & Palmer & $64.77^{\circ} \mathrm{S}$ & $64.05^{\circ} \mathrm{W}$ & Antarctica & Medium \\
9 & King George Island & $62.18^{\circ} \mathrm{S}$ & $58.30^{\circ} \mathrm{W}$ & Antarctica & Medium \\
10 & Cape Grim & $40.68^{\circ} \mathrm{S}$ & $144.68^{\circ} \mathrm{E}$ & Tasmania & Medium \\
11 & Cape Point & $34.35^{\circ} \mathrm{S}$ & $18.48^{\circ} \mathrm{E}$ & South Africa & Medium \\
12 & Norfolk Island & $29.08^{\circ} \mathrm{S}$ & $167.98^{\circ} \mathrm{E}$ & S.W. Pacific & Medium \\
$13 *$ & Jabiru & $12.70^{\circ} \mathrm{S}$ & $132.90^{\circ} \mathrm{E}$ & N. Australia & Medium \\
14 & Hawaii & $21.33^{\circ} \mathrm{N}$ & $157.70^{\circ} \mathrm{W}$ & N. Pacific & Medium \\
15 & Midway Island & $28.22^{\circ} \mathrm{N}$ & $177.35^{\circ} \mathrm{W}$ & N. Pacific & Medium \\
16 & Mace Head & $53.32^{\circ} \mathrm{N}$ & $9.85^{\circ} \mathrm{W}$ & Ireland & Medium \\
\hline $17 *$ & Rukomechi & $16.00^{\circ} \mathrm{S}$ & $29.50^{\circ} \mathrm{E}$ & Zimbabwe & High \\
18 & Barbados & $13.17^{\circ} \mathrm{N}$ & $59.43^{\circ} \mathrm{W}$ & Caribbean & High \\
19 & Miami & $25.75^{\circ} \mathrm{N}$ & $80.25^{\circ} \mathrm{W}$ & Florida, USA & High \\
20 & Hedo & $26.92^{\circ} \mathrm{N}$ & $128.25^{\circ} \mathrm{E}$ & East China Sea & High \\
21 & Bermuda & $32.27^{\circ} \mathrm{N}$ & $64.87^{\circ} \mathrm{W}$ & Caribbean & High \\
22 & Cheju & $33.52^{\circ} \mathrm{N}$ & $126.48^{\circ} \mathrm{E}$ & East China Sea & High \\
\hline & & & & & \\
\hline
\end{tabular}

several sites in this area. Both wet and total depositions in CanAM4-PAM are 10-20\% lower in summer than observations from FAMS (not shown). Therefore the likely reason for an underestimation of dust at Central American sites is an inefficient transport of Saharan dust across the Atlantic. The weak deposition in model may also contribute to the overestimation in coarse mode aerosol at Caribbean-American sites as shown in Sect. 3.2.

Observed concentrations at two Asian sites (20 and 22, Hedo and Cheju) peak in spring when Asian dust prevails. 
Two Pacific sites (14 and 15, Hawaii and Midway Island), are farther from the continent and less influenced by the Asian plume. Although the model captures the peak with good timing (Fig. 10), the simulated concentrations are lower at the two Asian sites and higher than observations at the two Pacific sites. This indicates that the transport of dust from Asia to the remote Pacific is likely too efficient in CanAM4-PAM. As was shown in Sect. 3.3, high concentrations near Asian dust sources are well reproduced by CanAM4-PAM. It is not clear why the transport of dust to the remote Pacific is too efficient in the model. Deposition data (Sect. 3.5) does not provide evidence for underestimates in deposition rate in the model, which would explain the high concentrations in the remote Pacific.

At the three sites around Australia (10, 12 and 13, Cape Grim, Norfolk Island and Jabiru) model results are mainly underestimated and fail to capture the seasonal peaks, which is similar to the behaviour of other models (Huneeus et al., 2011). This may indicate a lack of dust emissions from Australia in the model.

Figure 11 is similar to panels (a) and (b) of Fig. 6 in Huneeus et al. (2011). Biases at sites under dust influence and at sites downwind of dust sources are not deviated from other models (Huneeus et al., 2011). But biases at remote sites are overall positive in CanAM4-PAM.

In summary, CanAM4-PAM is able to simulate the seasonal cycle of dust concentration near major sources in the Northern Hemisphere. However, the gradient of dust magnitude away from the source regions is not well captured, which indicates a necessity for improving the efficiency of dust transport in the model. Localized and minor desert regions in Australia and South Africa are not well represented in CanAM4-PAM.

\subsection{Dust deposition}

The observed dust deposition provides a global constraint on the dust budget. A compiled dataset from multiple measurements has previously been applied for GCM evaluation (Huneeus et al., 2011). In this dataset, deposition rates over land are available from three data sources (Ginoux et al., 2001; Mahowald et al., 1999, 2009). Marine measurements are taken from The Dust Indicators and Records of Terrestrial and MArine Palaeoenvironments (DIRTMAP) dataset, which is based on records from ice cores and terrestrial (loess) deposits (Kohfeld and Harrison, 2001). Locations of all stations in the compiled dataset are shown in Fig. 12. Stations are grouped according to region and shown in different colors in Figs. 12 and 13. Detailed information about each station (name, latitude, longitude and the original reference) is available in the supplement of Huneeus et al. (2011).

A total rate of dry and wet deposition is diagnosed from the climate run of CanAM4-PAM and compared with the compiled data in Fig. 13. Model biases are mostly within a factor of ten in comparison to the observation. The largest

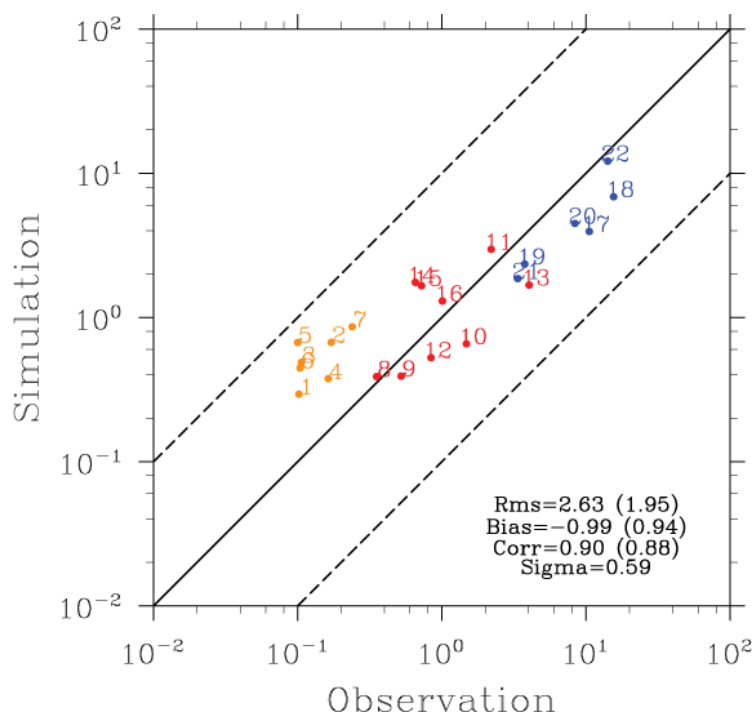

Fig. 9. Comparison of annual mean dust surface concentrations $\left(\mu \mathrm{g} \mathrm{m}^{-3}\right)$ at 22 sites. Measurements are from the extended University of Miami dataset. Simulations are from a 5-yr climatology run with CanAM4-PAM. Sites are grouped according to the concentration range and distance from the sources as shown in Fig. 8: remote sites (orange), sites under influence of dust sources (red) and sites downwind of major dust sources (blue). Locations of each site are listed in Table 6. Root mean square error (Rms), bias, correlation (Corr) and ratio of modelled to observed standard deviation (sigma) are indicated. Normalized root mean square error and mean normalized bias are given in the parenthesis next to Rms and Bias. The correlation with respect to the logarithm of the model results and of the observation is given in the parenthesis next to Corr. Black solid line is the $1: 1$ line and black dash lines are $10: 1$ and $1: 10$ lines.

differences occur at remote locations such as for Greenland and Southern Ocean. Overestimates in deposition rates are consistent with results from other models (Fig. 1 in Huneeus et al., 2011).

Deposition rates for West Africa are well aligned with the $1: 1$ line (orange and black symbols), which is consistent with accurate simulations of dust emissions in this region (Sect. 3.2). However, deposition rates are low at the two stations in Central America (E and 48 in orange), which points at insufficient transport of Saharan dust across the Atlantic in CanAM4-PAM as analyzed in Sect. 3.4.

Simulated and observed deposition rates agree well for the West Pacific (red symbols). On the other hand, deposition rate at four stations in the East Pacific (66, B, D and F in brown) are overestimated. The only station in a major Asian desert region $(\mathrm{H})$ shows insufficient deposition in CanAM4PAM. These provide additional evidences for excessive dust transport from Asia and to the remote Pacific sites (Sect. 3.4).

Simulated deposition rates at stations in the Middle East (dark green) are overestimated. In Sect. 3.2 the model predicts a relatively high volume concentration of dust particles at large size at Middle Eastern locations, which is in agreement with these results. 

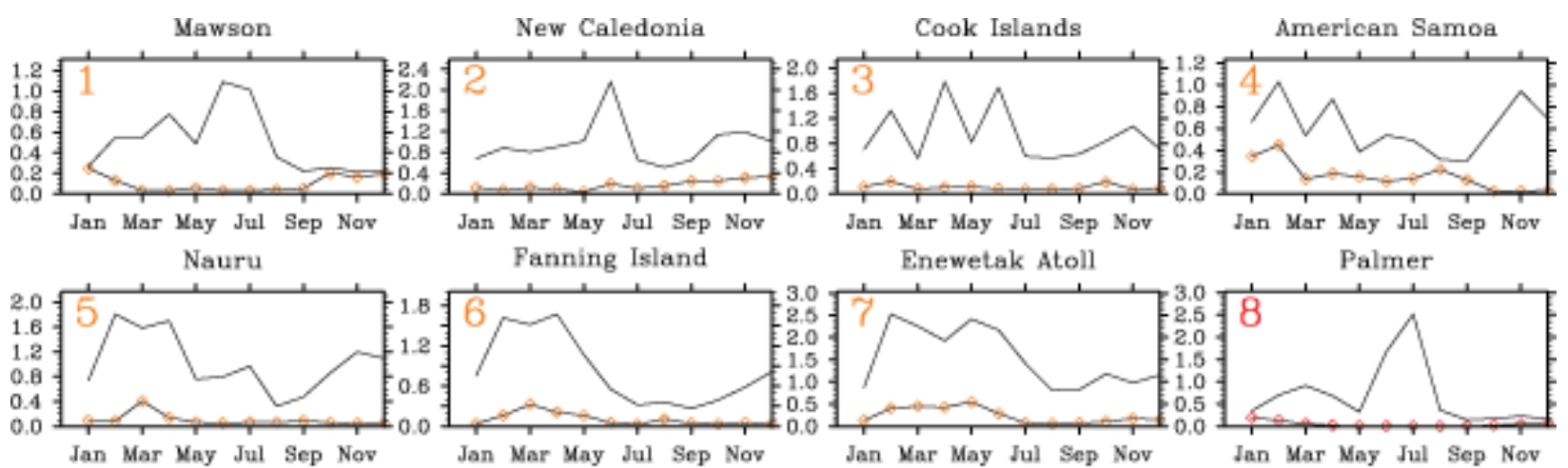

Fanning Island

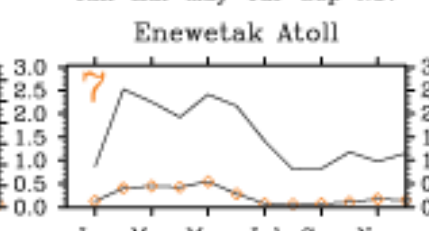

Palmer
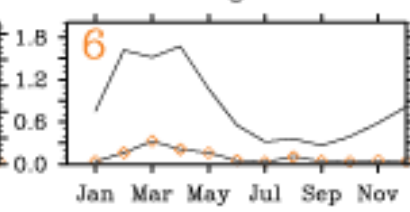

Jan Mar May Jul Sep Nov

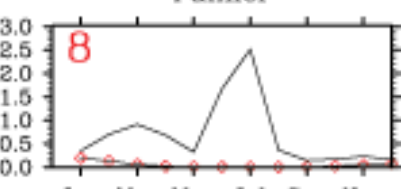

King George Island

Cape Grim
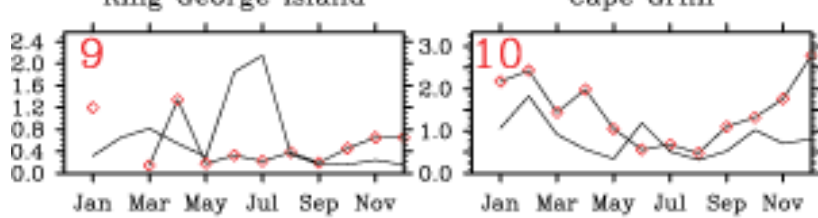

Cape Point

Jan Mar May Jul Sep Nov

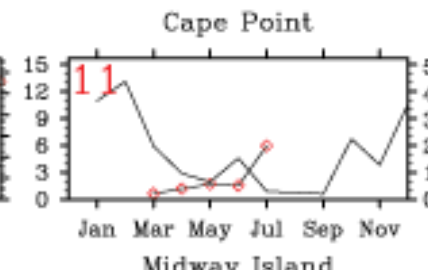

Norfolk Island

Jabiru

Hewaii

Midway Island
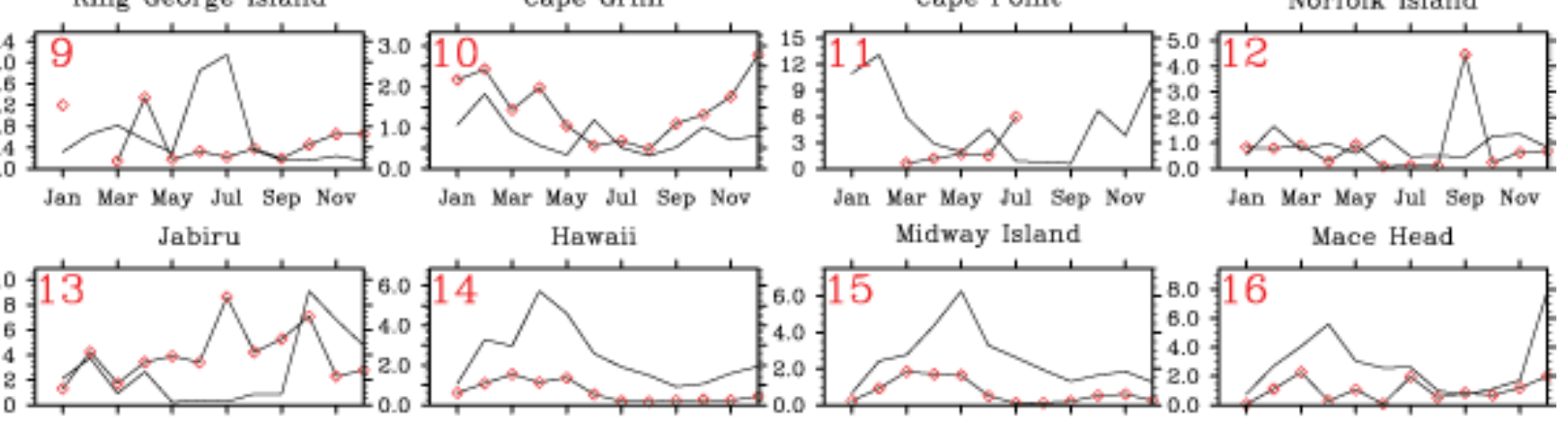

Jan Mar Nay Jul Sep Nov

Jan Mar May Jul Sep Nov

Jan Mar May Jul Sep Nov

Jan Mar May Jul Sep Nov
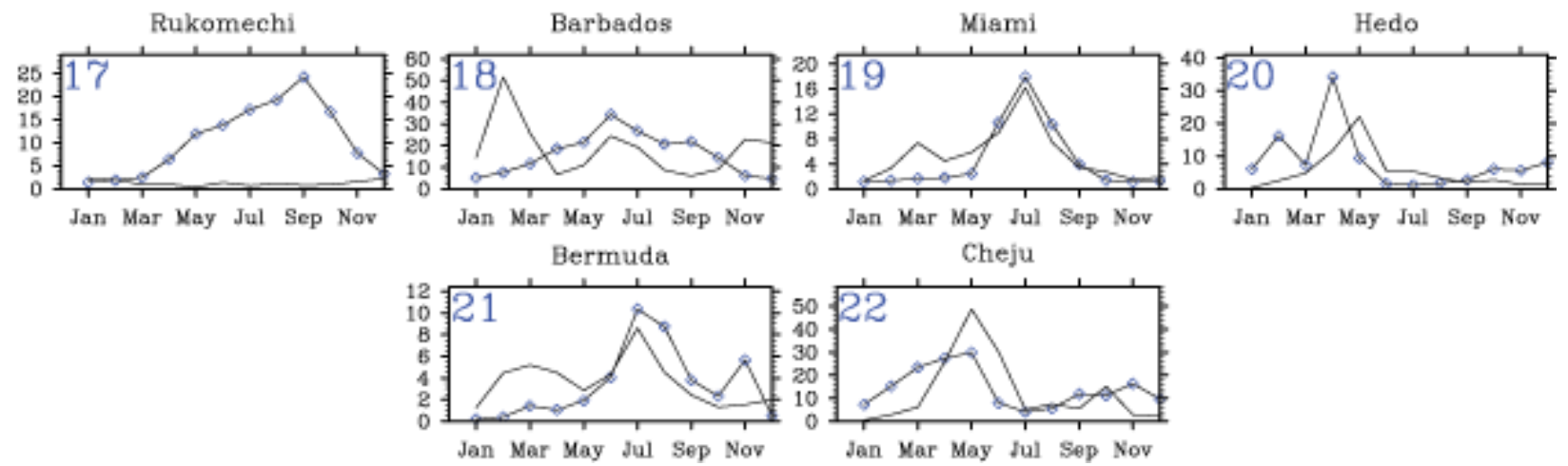

Cheju

Fig. 10. Comparison for monthly mean surface dust mass concentrations $\left(\mu \mathrm{g} \mathrm{m}^{-3}\right)$ at 22 sites from the extended University of Miami dataset. Black curves are model results from the climate run of CanAM4-PAM. Color and number in each panel are corresponding to the three groups as in Figs. 8 and 9: remote sites (orange), sites under influence of dust sources (red) and sites downwind the major dust sources (blue). Name, latitude and longitude of each site are listed in Table 6 . Note that the vertical scale is different in each panel.

Results shown in Fig. 13 is similar to Fig. 1 of Huneeus et al. (2011), in which biases of 15 models are between -11.4 and -5.1 . The bias of CanAM4-PAM is within this range (-9.91). The correlation of CanAM4-PAM results is 0.29 and within the range of 0.15 to 0.84 from Huneeus et al. (2011). Model deviations at remote stations and in Asia are similar in CanAM4-PAM and other models (Huneeus et al., 2011).

In summary, model results for surface measurements of size distributions, mass concentrations, and deposition rates are in reasonable agreement with observations. Results are in general consistency with other global climate models as analyzed in Huneeus et al. (2011). Dust plume extension and seasonal distribution are realistic in and around the major global source regions, but detailed features are not represented very well. The largest discrepancies between model simulation and observations occur in remote areas far from the dust sources, where the model tends to overestimate aerosol amounts and deposition.

\section{Validation with satellite measurements}

Satellite data have been widely used to study aerosol effects on the large scale (Kaufman et al., 2002) and for validation of GCM simulations (e.g., Kinne et al., 2006). In this section model results are mainly compared with retrieved data 

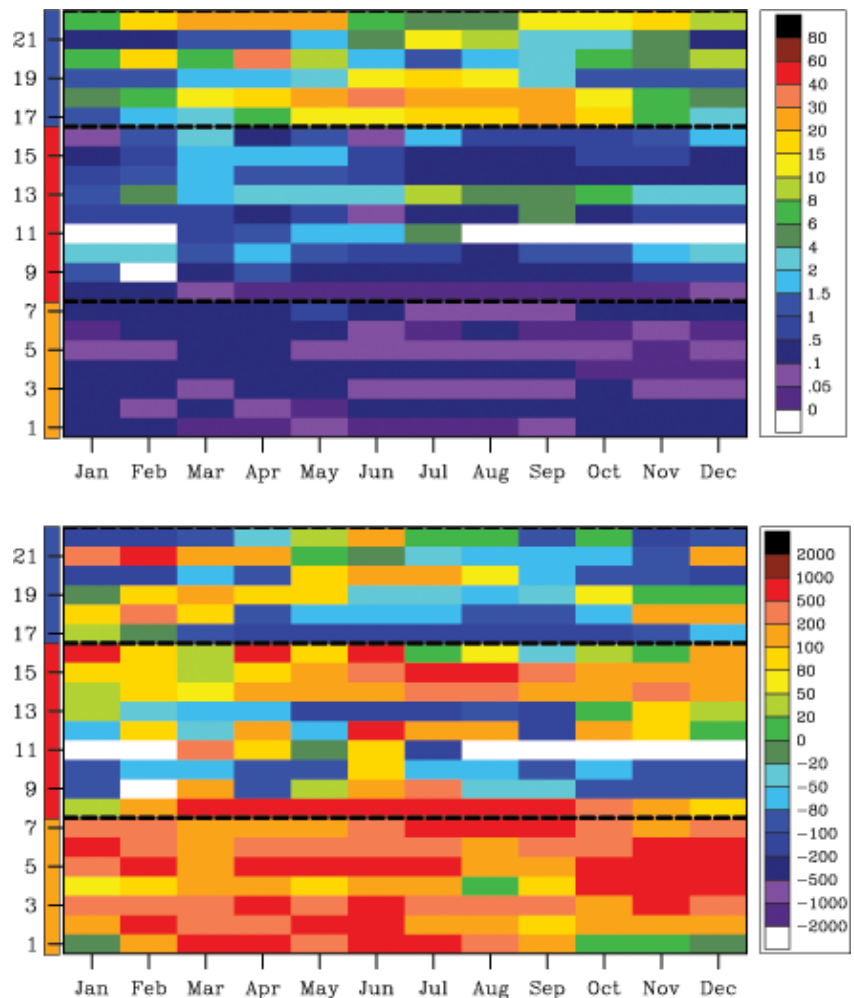

Fig. 11. Observed monthly mean surface dust mass concentrations ( $\mu \mathrm{g} \mathrm{m}^{-3}$, upper panel) and biases (\%, lower panel) of modelled to observed dust concentration at 22 sites from the extended University of Miami dataset. The ordinate refers to the number of sites and colors are corresponding to the three groups as in Figs. 8 and 9: remote sites (orange), sites under influences of dust sources (red) and sites downwind the major dust sources (blue). Name, latitude and longitude of each site are listed in Table 6. Blank bars indicate missing data.

from satellites, in particular for aerosol optical depth (AOD) at $0.55 \mu \mathrm{m}$ wavelength and shortwave (SW) aerosol direct radiative forcing (ADRF). AOD is also compared with the remote sensing measurements from AERONET at "dusty" sites (see Sect. 3.2).

\subsection{Aerosol Optical Depth (AOD)}

This subsection focuses on the total AOD instead of the dust AOD for comparison with global satellite observations. Recent studies have attempted to distinguish dust aerosol from other aerosol types on both regional and global scales (e.g., Kalashnikova et al., 2011). However retrievals of total AOD are likely more robust than more specific retrievals for dust AOD, which require additional information about dust properties. Previous work has demonstrated that the mean AOD over and near major dust source regions is dominated by contributions from dust, with only minor contributions from nondust aerosols.
Three datasets of retrieved AOD from satellites are applied for comparisons with model results. The first is based on measurements from the MODerate Resolution Imaging Spectroradiometer (MODIS), which is onboard NASA's platform (Remer et al., 2005). For this study, archived data from the monthly level-3 product is used (Abdou et al., 2005), which is in combination with the deepblue product to specifically retrieve aerosols over the reflective surfaces such as deserts. Another retrieval dataset is available from measurements with the Multiangle Imaging SpectroRadiometer (MISR). The instrument is able to provide reliable retrievals both over land and ocean. The monthly mean of MISR AOD of version 3.1 product is used for this study (Kahn et al., 2005). Both MODIS and MISR data are available online through the NASA Giovanni interface (http://disc.sci.gsfc. nasa.gov/giovanni/).

In order to complement the MODIS and MISR datasets, a combined MODIS/MISR dataset from van Donkelaar et al. (2006, 2010) was also considered for this study. For this dataset, the retrieved albedo from MODIS is used to divide the Earth's surface into different domains. Monthly averaged MODIS and MISR AOD are then compared against groundbased measurements of AOD from AERONET within each domain to filter out satellite data which produce poor agreement with AERONET. Both MODIS and MISR AOD data with fine mode fractions smaller than $20 \%$ are also filtered out to reduce the influence of large particles on the retrieval. AOD after albedo-filtering and fine-mode-filtering are provided as a combined dataset (between $60^{\circ} \mathrm{S}$ and $75^{\circ} \mathrm{N}$ ) from year 2001 to 2006 with a resolution of $0.1^{\circ} \times 0.1^{\circ}$. Grid points without data near the poles are zeroed.

For comparisons with satellite retrievals, CanAM4-PAM is run with nudging for years 2001 to 2006. Model captures the main aerosol plumes over West Africa, Middle East and East Asia (Fig. 14), where dust is the dominant type of aerosol. For West Africa the model tends to overestimate the AOD, which is consistent with the high particle volume in this region as shown in Sect. 3.2. The AOD is also too high over the Arabian Peninsula and adjacent regions. This is consistent with the high dust particle volume (Sect. 3.2) and deposition rate (Sect. 3.5) in the Middle East.

Sulfate and BC aerosols from human activity, in addition to dust aerosols transported from inland deserts during dusty seasons are expected to contribute to a simulated high AOD over East Asia. Model results are consistent with satellite estimates for the Asian plume over the North Pacific, but extends a little further in the model simulation. On the contrary, the simulated Saharan plume is less extensive than observed,

The global mean AOD $\left(60^{\circ} \mathrm{S}\right.$ to $\left.75^{\circ} \mathrm{N}\right)$ of the total aerosol is 0.138 from the model simulation, which is higher than the AOD of the combined dataset (0.129). By excluding points with missing data in MODIS and MISR, CanAM4-PAM AOD are 0.124 and 0.122 respectively. Both are higher than satellite retrievals from MODIS (0.108) and MISR (0.112). 


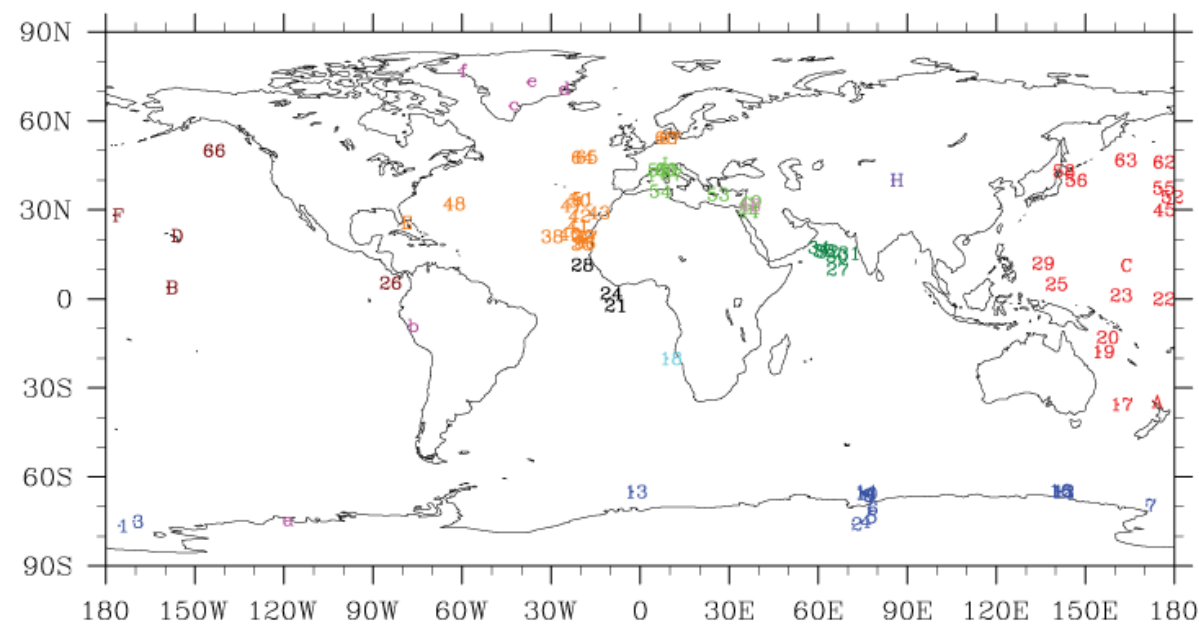

Fig. 12. Location of stations from the compiled dust deposition dataset. Different colors are applied for different regions: West/East Pacific (red/brown), North/Tropical/South Atlantic (orange/black/light-blue), Middle East/Asia/Europe (violet/purple/light green), Indian/Southern Ocean (dark green/dark blue) and pink ice core data in Greenland, South America and Antarctica.

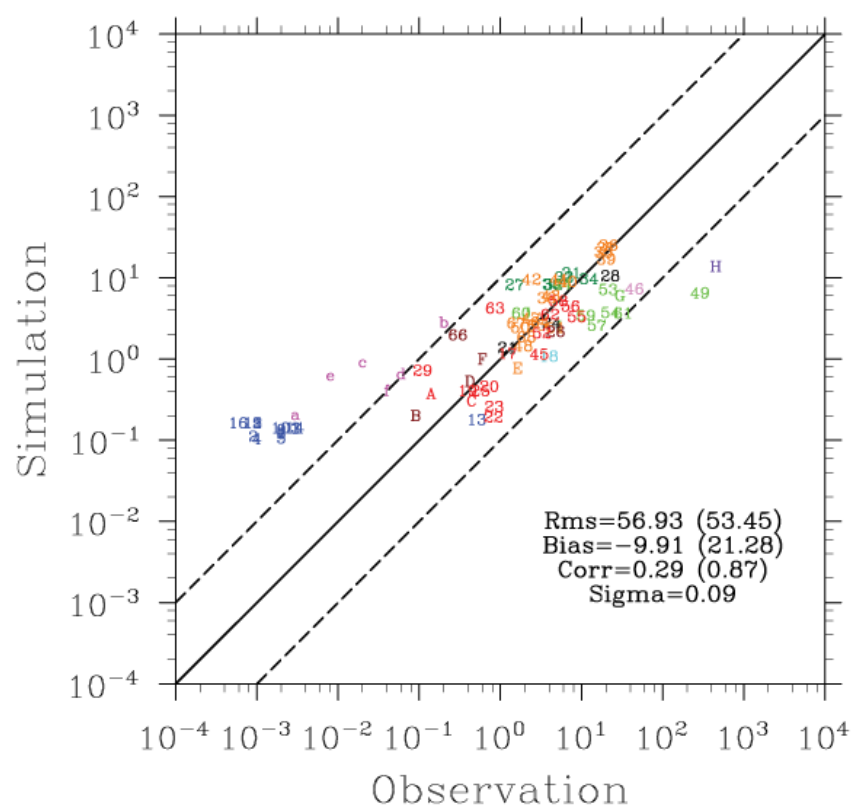

Fig. 13. Comparison between modelled and compiled data of dust deposition rates $\left(\mathrm{g} \mathrm{m}^{-2} \mathrm{yr}^{-1}\right)$. Stations are grouped regionally as shown in Fig. 12. Root mean square error (Rms), bias, correlation (Corr) and ratio of modelled to observed standard deviation (sigma) are indicated. Normalized root mean square error and mean normalized bias are given in the parenthesis next to Rms and Bias. The correlation with respect to the logarithm of the model results and of the observation is given in the parenthesis next to Corr. Black solid line is the $1: 1$ line and black dash lines are $10: 1$ and $1: 10$ lines.

It is likely that non-dust aerosol species are also contributing to the biases.

Figure 15 shows the seasonal variation of model results in comparison with satellite measurements of AOD. In win- ter, West Africa is the main source of dust on the globe. Spring is the most dusty season, especially in Asia. The Asian plume covers a large area and reaches to the west coast of Canada and the US. High AOD values occur for West Africa and the Middle East in summer, which is well represented by the simulation. The highest AOD values occur during spring and summer and are located over Asia, which can be attributed to both dust and sulfate/carbonaceous aerosols. However, CanAM4-PAM fails to reproduce the large AOD in the Southern Hemisphere during boreal winter and autumn, especially in localized desert regions such as the west coast of South America and South Africa.

\subsection{AERONET AOD}

The modelled AOD is compared with AERONET measurement (Fig. 16) at "dusty" sites as defined in Sect. 3.2. AERONET AOD data are extracted for year 2001-2006 so that they are comparable to results of the nudged run with CanAM4-PAM.

Model overestimations for West Africa (orange) and the Middle East (red) are consistent with the comparison to satellite data in Sect. 4.1. Similarly is the underestimation at Caribbean-American sites (blue). Figure 16 is based on the same dataset as Fig. 9 in Huneeus et al. (2011). Results in Huneeus et al. (2011) are for year 2000 whereas CanAM4PAM results are for 2001-2006. Biases of 15 models in Huneeus et al. (2011) are from -0.14 to 0.09 . The bias of CanAM4-PAM is within this range (0.01). The correlation between CanAM4-PAM results and observed data is 0.74 , which is in the range of 0.54 to 0.86 from Huneeus et al. (2011).

Dust AOD simulated in CanAM4-PAM and other models are summarized in Table 3. CanAM4-PAM results are within 

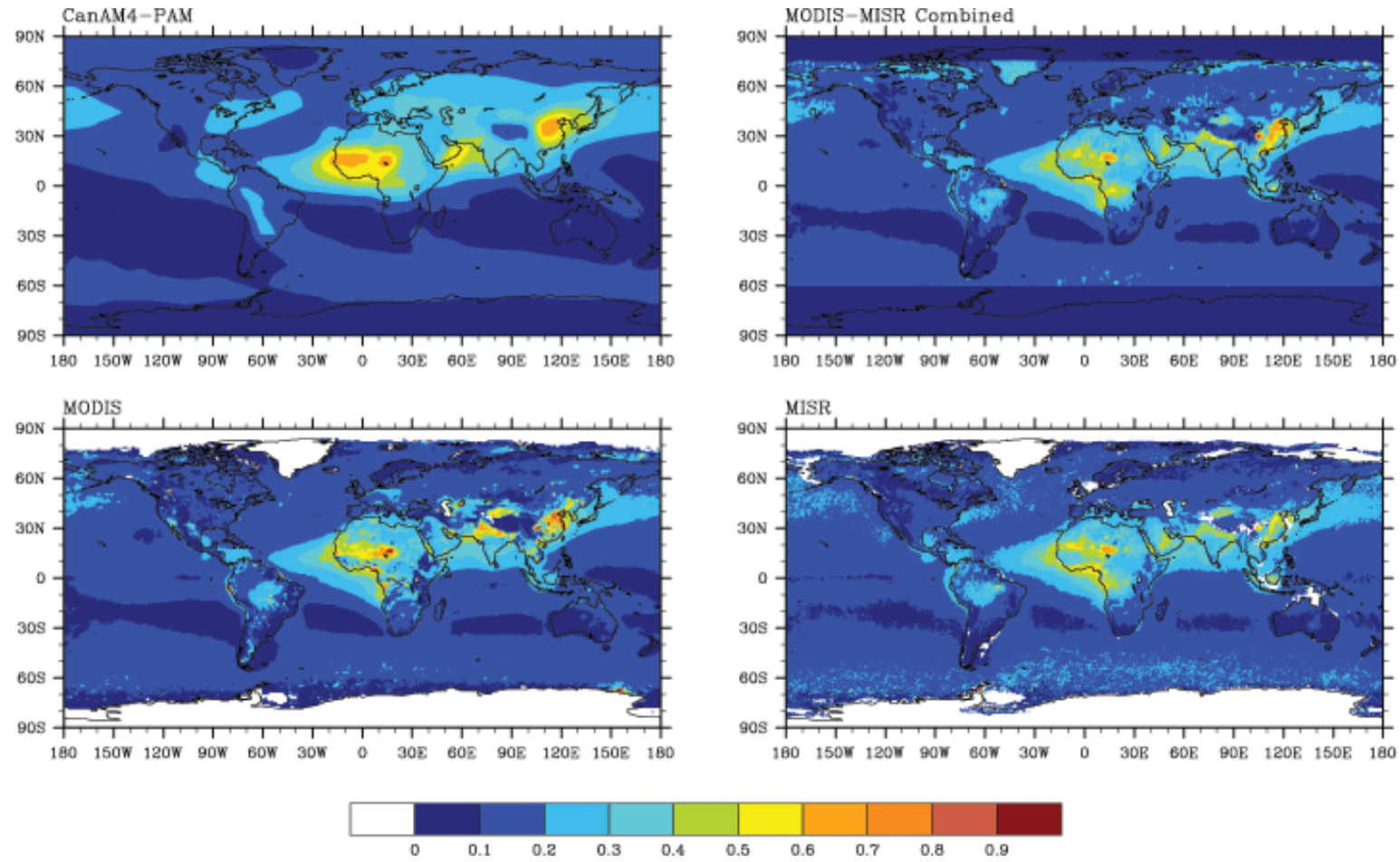

Fig. 14. Comparison between model results and satellite measurements of annual mean total aerosol optical depth (AOD) at $0.55 \mu \mathrm{m}$ for time period 2001-2006. Results of CanAM4-PAM are from a nudged simulation (top left). Satellite retrievals from MODIS (bottom left), MISR (bottom right) and from a hybrid dataset (top right) are shown. Areas with missing values appear white.

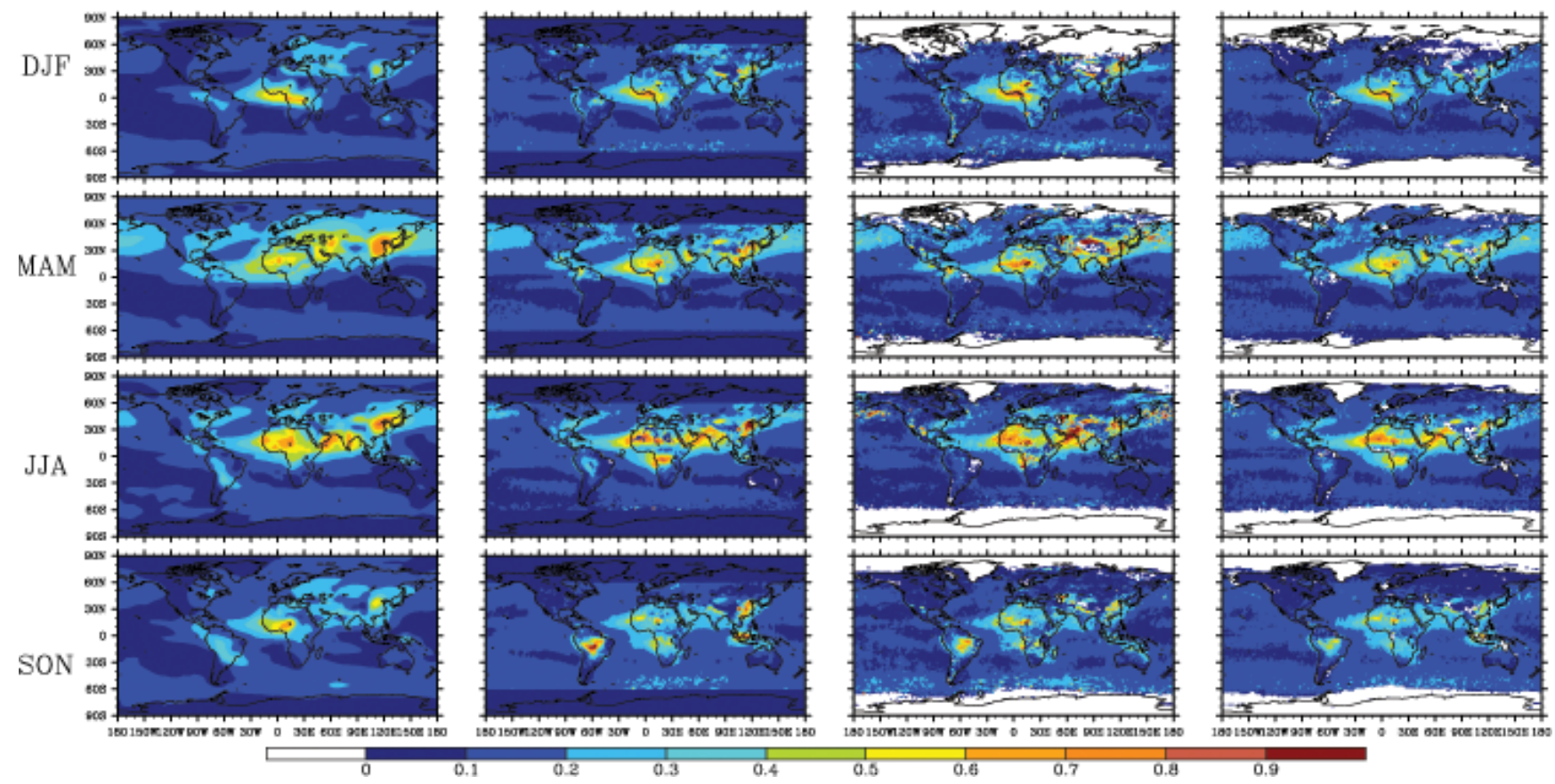

Fig. 15. Same as Fig. 14 but for seasonal means. Rows from the top to the bottom are winter (DJF), spring (MAM), summer (JJA) and autumn (SON). Columns from the left to the right are CanAM4-PAM results, combined dataset, MODIS and MISR data, respectively. 


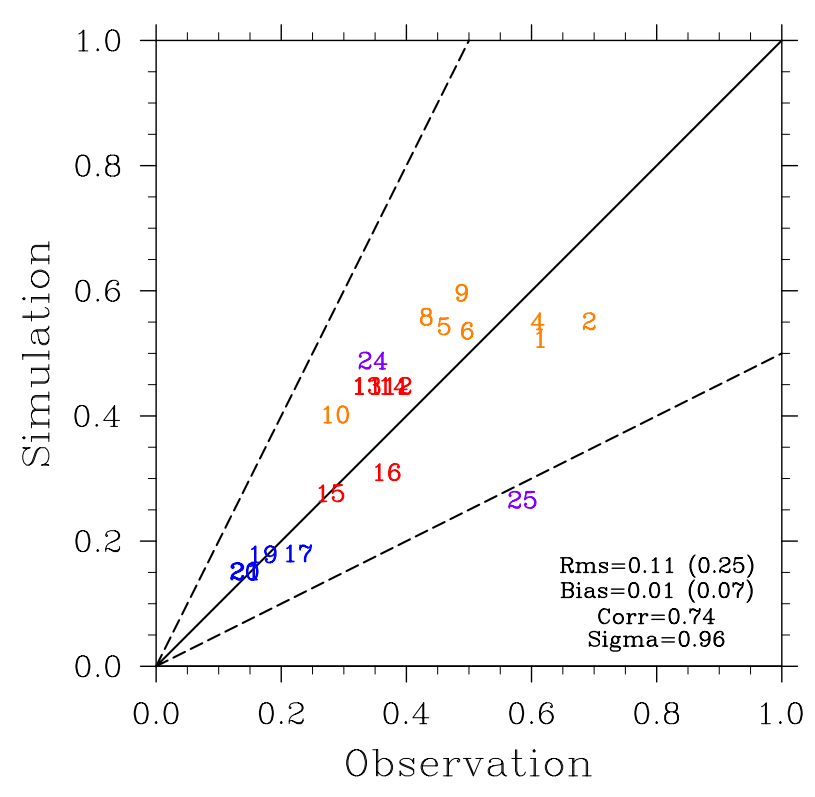

Fig. 16. AOD comparison between AERONET measurements and CanAM4-PAM results at "dusty" sites. The locations of "dusty" sites are shown in Fig. 4: Middle East (red), Africa (orange), Caribbean-America (blue) and elsewhere in the world (purple). Name, latitude and longitude of each site are listed in Table 4. Root mean square error (Rms), bias, correlation (Corr) and ratio of modelled to observed standard deviation (sigma) are indicated. Normalized root mean square error and mean normalized bias are given in the parenthesis next to Rms and Bias. Black solid line is the $1: 1$ line and black dash lines are $2: 1$ and $1: 2$ lines. Sites $3,7,18$, 22 and 23 are not shown because of the lack of data in the period 2001-2006.

the range of multiple model estimates from two AeroCom experiments and agree well with results from other studies.

\subsection{Aerosol Direct Radiative Forcing (ADRF)}

MODIS measures the clear-sky SW radiances, which can be converted to TOA SW fluxes with empirical Angular Distribution Models (ADMs) developed from CERES (Clouds and the Earth's Radiant Energy System) following the procedure in Loeb et al. (2005). The TOA ADRF is then derived from the SW fluxes by using the approach of Loeb and Smith (2005). The MODIS/CERES ADRF product is for total aerosol only. For contributions of individual types of aerosols to the total ADRF, Zhao et al. (2010) calculates the AOD ratio of sulfate, sea salt, dust, BC and OC to the total aerosol AOD according to simulation results from the Goddard Global Ozone Chemistry Aerosol Radiation and Transport (GOCART) model. Both total ADRF and component ADRF are available with a resolution of $1^{\circ} \times 1^{\circ}$ for year 2001 (Zhao et al., 2010).

Simulated ADRF at TOA for the year 2001 for clear-sky conditions are compared to MODIS/CERES ADRF as well as the derived dust ADRF in Fig. 17. Satellite data are not reliable in polar regions and are therefore ignored. ADRF over continents is also masked out because the land surface albedo influences the ADRF. The current GCM estimate and satellite retrieval of ADRF show a variety of dependences on the land surface albedo assumptions, especially in desert and snow covered regions (e.g., Schulz et al., 2006; Yu et al., 2006). Thus ADRF is only plotted over ocean in Fig. 17 (e.g., Myhre et al., 2009).

Figure 17 shows a good agreement for the dust forcing. Both magnitude and position of dust plumes off West Africa and Middle East are consistent with the satellite data. The extension of Asian dust plume to the North Pacific agrees to the observation. While the Saharan plume and Middle East plume are both overestimated in this specific year.

The total ADRF from CanAM4-PAM simulation is less negative around $10^{\circ} \mathrm{S}$ to $10^{\circ} \mathrm{N}$ off the west coast of central Africa, which is likely due to the missing OC sources from biomass burning. A relatively weak forcing of Asian aerosol over the North Pacific may be attributed to the underestimation of $\mathrm{BC}$ and sulfate aerosols. The less negative forcing over the ocean in the Southern Hemisphere could be due to sea salt (figures of non-dust aerosols are not shown).

In general, the simulated ADRF of dust and total aerosols over ocean exhibit consistent global patterns with the satellite data. The dust ADRF from CanAM4-PAM is also compared with estimates from other studies in Table 3 . The wide range of ADRF indicates a large uncertainty in aerosol forcings from GCMs.

\section{Conclusions}

A size-resolved numerical scheme in an experimental version of the fourth generation Canadian Atmospheric Global Climate Model (CanAM4-PAM) is applied to simulations of the global dust cycle. In the model, emission, transport as well as deposition of dust aerosols are parameterized in terms of the size distribution of particles. The simulated global mean emission amount and mass burden of dust aerosols are within the range of estimates from other GCMs. CanAM4-PAM shows a general agreement with observations for size distributions, mass concentrations and deposition rates from multiple surface-based datasets. Deviations of model from observations are analyzed. Consistent biases are attributed to the representation of emissions from major sources and biases in long-range transport across Northern Hemispheric oceans, indicating the need for improvements in parameterizations of these processes.

Overall, the model reproduces observed concentrations of dust over and near major dust sources such as West Africa, Middle East and East Asia. However, secondary sources, especially sources in the Southern Hemisphere are not very well represented in the model. Compared to large desert regions in the Northern Hemisphere, deserts in South America, South Africa and Australia are rather sparse. Results of 


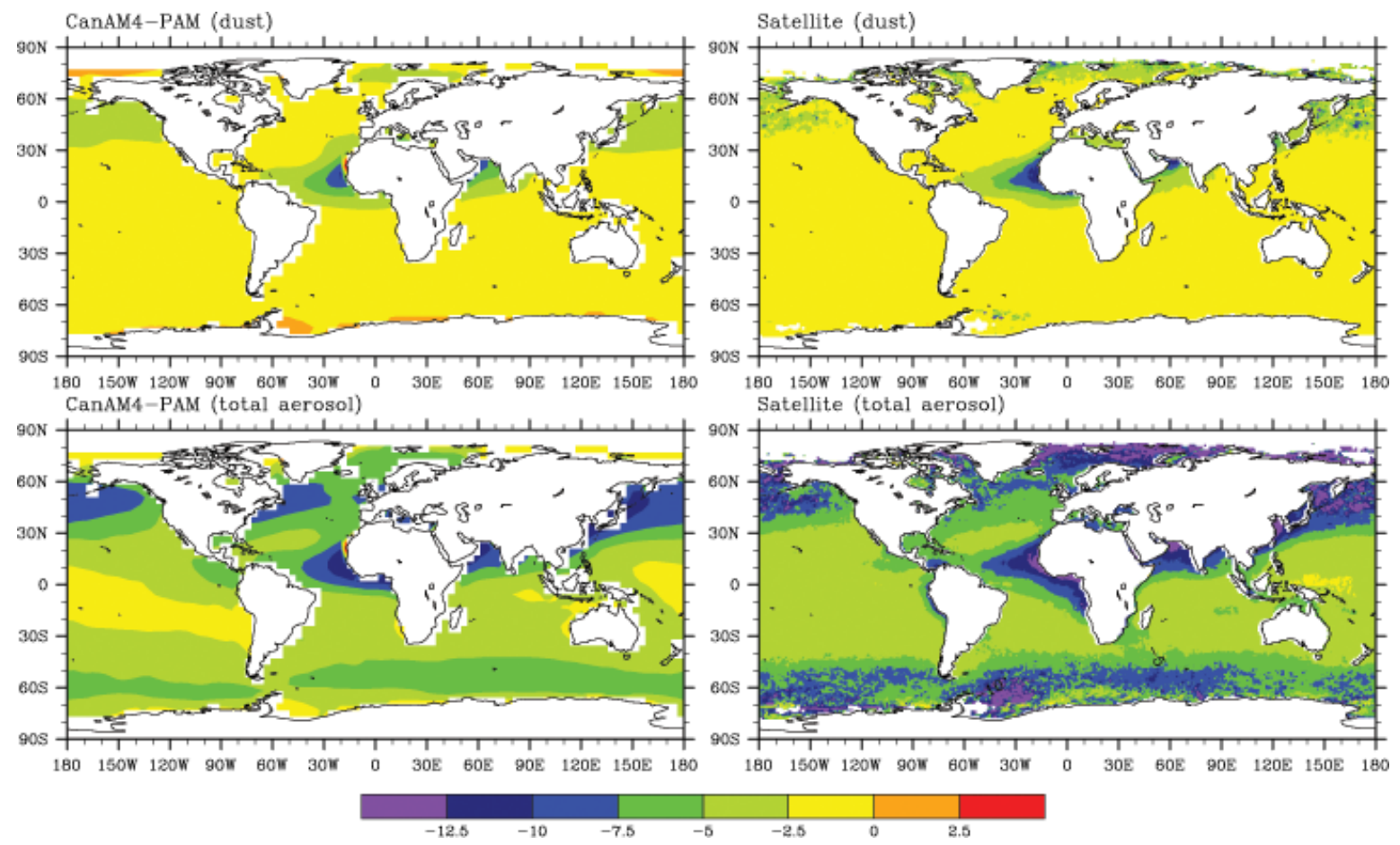

Fig. 17. ADRF comparison between satellite measurements and CanAM4-PAM results for dust and total aerosols over the ocean. Unit is $\mathrm{W} \mathrm{m}^{-2}$. Data are for year 2001 .

CanAM4-PAM for surface concentration, deposition rate and AOD at "dusty" sites agree well with results from a previous study of Huneeus et al. (2011). Observations on aerosol size distributions and dust surface concentrations for Asia provide additional evidence for realistic simulations of dust aerosol with CanAM4-PAM.

In Sect. 4, both AOD and ADRF of dust aerosol are compared with satellite retrieval and other model estimates. In this study, the size distribution of dust aerosol is traced through the microphysics scheme in CanAM4-PAM. However, only the mass mixing ratio from the PLA scheme is currently applied to the radiation scheme. In a future study, aerosol radiative calculation will be improved in CanAM4PAM. PLA size parameters in addition to the mass mixing ratio will be consistently used for radiation calculations, which may help to simulate the radiative properties more accurately. More detailed observational datasets are expected to provide an improved basis for validation of aerosol optical properties in the future.

There are no direct measurements of aerosol size distribution on a global scale. As most GCMs are expected to soon include schemes for size-resolved simulation of aerosols, an integrated dataset with global aerosol size information is needed. Moreover, both AOD and ADRF datasets from satellite retrieval are 2-dimensional in this study. The recent satellite retrieval can provide layered data of aerosol properties, such as data from the Cloud-Aerosol Lidar and Infrared Pathfinder Satellite Observation (CALIPSO) applied in Liu et al. (2008) and Yu et al. (2010). These datasets also help to understand and simulate dust aerosol more realistically in GCMs.

Acknowledgements. This study is part of the CAFC (CloudAerosol Feedbacks and Climate) network, which is funded by CFCAS (Canadian Foundation for Climate and Atmospheric Science). We thank Ina Tegen and Birgit Wehner for providing the dust emission input data and observational data in Beijing, respectively. Thomas Diehl from NASA is acknowledged for his help with the emission data of sulfate, BC and OC aerosols. We also thank for X.-P. Zhao and Norman Loeb for their help with the ADRF satellite data.

Edited by: Y. Balkanski

\section{References}

Abdou, W. A., Diner, D. J., Martonchik, J. V., Bruegge, C. J., Kahn, R. A., Gaitley, B. J., Crean, K. A., Remer, L. A., and Holben, B.: Comparison of coincident multiangle imaging spectroradiometer and moderate resolution imaging spectroradiometer aerosol optical depth over land and ocean scenes containing aerosol robotic network sites, J. Geophys. Res., 110, D10S07, doi:10.1029/2004JD004693, 2005.

Arimoto, R., Duce, R. A., Ray, B. J., Ellis, W. G., Cullen, J. D., and Merrill, J. T.: Trace-Elements in the Atmosphere over the North-Atlantic, J. Geophys. Res., 100, 1199-1213, doi:10.1029/94JD02618, 1995. 
Arimoto, R., Ray, B. J., Lewis, N. F., and Tomza, U.: Mass-particle size distribution of atmospheric dust and the dry deposition of dust to the remote ocean, J. Geophys. Res., 102, 15867-15874, doi:10.1029/97JD00796, 1997.

Arora, V. and Boer, G.: A parameterization of leaf phenology for the terrestrial ecosystem component of climate models, Glob. Change Biol., 11, 39-59, doi:10.1111/j.13652486.2004.00890.x, 2005.

Balkanski, Y., Shculz, M., Claquin, T., and Guibert, S.: Reevaluation of mineral dust aerosol radiative forcings suggests a better agreement with satellite and AERONET data, Atmos. Chem. Phys., 7, 81-95, doi:10.5194/acp-7-81-2007, 2007.

Bäumer, D., Lohmann, U., Lesins, G., Li, J., and Croft, B.: Parameterizing the optical properties of carbonaceous aerosols in the Canadian Centre for Climate Modeling and Analysis Atmospheric General Circulation Model with impacts on global radiation and energy fluxes, J. Geophys. Res., 112, D10207, doi:10.1029/2006JD007319, 2007.

Berge, E.: Coupling of wet scavenging of sulphur to clouds in a numerical weather prediction model, Tellus, 45B, 1-22, 1993.

Boer, G. J.: A hybrid moisture variable suitable for spectral GCMs, in: Research Activity in Atmospheric and Oceanic Modelling, Report No. 21, WMO/TD 665, Geneva, Switzerland, 1995.

Bothwell, G. W., Hansen, E. G., Vargo, R. E., and Miller, K. C.: The Multi-angle Imaging SpectroRadiometer science data system, its products, tools and performance, IEEE T. Geosci. Remote Sens., 40, 1467-1476, doi:10.1109/TGRS.2002.801152, 2002.

Braswell, B. H., Schimel, D. S., Linder, E., and Moore, B.: The response of global terrestrial ecosystems to interannual temperature variability, Science, 278, 870-872, 1997.

Cakmur, R. V., Miller, R. L., Perlwitz, J., Koch, D., Geogdzhayev, I. V., Ginoux, P., Tegen, I., and Zender, C. S.: Constraining the global dust emission and load by minimizing the difference between the model and observations, J. Geophys. Res., 111, D06207, doi:10.1029/2005JD005791, 2006.

Cheng, T., Peng, Y., Feichter, J., and Tegen, I.: An improvement on the dust emission scheme in the global aerosol-climate model ECHAM5-HAM, Atmos. Chem. Phys., 8, 1105-1117, doi:10.5194/acp-8-1105-2008, 2008.

Croft, B., Lohmann, U., and von Salzen, K.: Black carbon aging in the Canadian Centre for Climate Modelling and Analysis General Circulation Model, Atmos. Chem. Phys, 5, 1383-1419, doi:10.5194/acp-5-1931-2005, 2005.

Diner, D. J., Beckert, J., Reilly, T., Bruegge, C., Conel, J., Kahn, R., Martonchik, J., Ackerman, T., Davies, R., Gerstl, S., Gordon, H., Muller, J.-P., Myneni, R., Sellers, P., Pinty, B., and Verstraete, M.: Multi-angle Imaging SpectroRadiometer (MISR) description and experiment overview, IEEE T. Geosci. Remote Sens., 36, 1072-1087, doi:10.1109/36.700992, 1998.

Dobbie, S., Li, J., Harvey, R., and Chýlek, P.: Sea-salt optical properties and GCM forcing at solar wavelengths, Atmos. Res., 65, 211-233, 2003.

Dubovik, O. and King, M. D.: A flexible inversion algorithm for retrieval of aerosol optical properties from sun and sky radiance measurements, J. Geophys. Res., 105, 20673-20696, doi:10.1029/2000JD900282, 2000.

Fécan, F., Marticorena, B., and Bergametti, G.: Parametrization of the increase of the aeolian erosion threshold wind friction velocity due to soil moisture for arid and semi-arid areas, Ann. Geo- phys., 17, 149-157, doi:10.1007/s00585-999-0149-7, 1999.

Forster, P., Ramaswamy, V., Artaxo, P., Berntsen, T., Betts, R., Fahey, D., Haywood, J., Lean, J., Lowe, D., Myhre, G., Nganga, J., Prinn, R., Raga, G., Schultz, M., and Van Dorland, R.: Changes in atmospheric constituents and in radiative forcing, in: Climate change 2007: The physical science basis., in: Contribution of Working Group I to the Fourth Assessment Report of the Intergovernmental Panel on Climate, edited by: Solomon, S., Qin, D., Manning, M., Chen, Z., Marquis, M., Averyt, K. B., Tignor, M., and Miller, H. L., Cambridge University Press, Cambridge, United Kingdom and New York, NY, USA, 2007.

Ginoux, P. and Torres, O.: Empirical TOMS index for dust aerosol: Applications to model validation and source characterization, $\mathrm{J}$ Geophys. Res., 108, 4534, doi:10.1029/2003JD003470, 2003.

Ginoux, P., Chin, M., Tegen, I., Prospero, J., Holben, B., Dubovik, O., and Lin, S.-J.: Sources and distributions of dust aerosols simulated with the GOCART model, J. Geophys. Res., 16, 20255 20274, doi:10.1029/2000JD000053, 2001.

Gong, S. L., Barrie, L. A., Blanchet, J.-P., von Salzen, K., Lohmann, U., Lesins, G., Spacek, L., Zhang, L. M., Girard, E., Lin, H., Leaitch, R., Leighton, H., Chylek, P., and Huang, P.: Canadian Aerosol Module: A size-segregated simulation of atmospheric aerosol processes for climate and air quality models. 1. Module Development, J. Geophys. Res., 108, 4007, doi:10.1029/2001JD002002, 2003.

Hess, M., Koepke, P., and Schult, I.: Optical properties of aerosols and clouds: The software package OPAC, B. Am. Meteorol. Soc., 79, 831-844, 1998.

Holben, B. N., Eck, T. F., Slutsker, I., Tanre, D., Buis, J. P., Setzer, A., Vermote, E., Reagan, J. A., Kaufman, Y. J., Nakajima, T., Lavenu, F., Jankowiak, I., and Smirnov, A.: AERONET - A Federated Instrument Network and Data Archive for Aerosol Characterization, Remote Sens. Environ., 66, 1-16, 1998.

Holben, B. N., Tanre, D., Smirnov, A., Eck, T. F., Slutsker, I., Abuhassan, N., Newcomb, W. W., Schafer, J. S., Chatenet, B., Lavenu, F., Kaufman, Y. J., Vande Castle, J., Setzer, A., Markham, B., Clark, D., Frouin, R., Halthore, R., Karneli, A., O'Neill, N. T., Pietras, C., Pinker, R. T., Voss, K., and Ziborbi, G.: An emerging ground-based aerosol climatology: Aerosol optical depth from AERONET, J. Geophys. Res., 106, 1206712097, doi:10.1029/2001JD900014, 2001.

Huneeus, N., Schulz, M., Balkanski, Y., Griesfeller, J., Prospero, J., Kinne, S., Bauer, S., Boucher, O., Chin, M., Dentener, F., Diehl, T., Easter, R., Fillmore, D., Ghan, S., Ginoux, P., Grini, A., Horowitz, L., Koch, D., Krol, M. C., Landing, W., Liu, X., Mahowald, N., Miller, R., Morcrette, J.-J., Myhre, G., Penner, J., Perlwitz, J., Stier, P., Takemura, T., and Zender, C. S.: Global dust model intercomparison in AeroCom phase I, Atmos. Chem. Phys., 11, 7781-7816, doi:10.5194/acp-11-7781-2011, 2011.

Jickells, T. D., An, Z. S., Andersen, K. K., Baker, A. R., Bergametti, G., Brooks, N., Cao, J. J., Boyd, P. W., Duce, R. A., Hunter, K. A., Kawahata, H., Kubilay, N., laRoche, J., Liss, P. S., Mahowald, N., Prospero, J. M., Ridgwe, A. J., Tegen, I., and Torres, R.: Global iron connections between desert dust, ocean biogeochemistry and climate, Science, 308, 67-71, 2005.

Kahn, R. A., Gaitley, B. J., Martonchik, J. V., Diner, D. J., Crean, K. A., and Holben, B.: Multiangle Imaging SpectroRadiometer (MISR) global aerosol optical depth validation based on 2 years of coincident Aerosol Robotic Network 
(AERONET) observations, J. Geophys. Res., 110, D10S04, doi:10.1029/2004JD004706, 2005.

Kalashnikova, O. V., Garay, M. J., Sokolik, I. N., Diner, D. J., Kahn, R. A., Martonchik, J. V., Lee, J. N., Torres, O., Yang, W., Marshak, A., Kassabian, S., and Chodas, M.: Capabilities and limitations of MISR aerosol products in dust-laden regions, Proceedings of the SPIE, 8177, 81770O, doi:10.1117/12.897773, 2011.

Kaufman, Y. J., Tanre, D., Remer, L. A., Vermote, E., Chu, A., and Holben, B. N.: Opretional remote sensing of tropospgeric aerosol over land from EOS moderate resolution imaging spectroradiometer, J. Geophys. Res., 102, 17051-17067, doi:10/1029/96JD03988, 1997.

Kaufman, Y. J., Tanré, D., Dubovik, O., Karnieli, A., and Remer, L. A.: Absorption of sunlight by dust as inferred from satellite and ground-based remote sensing, Geophys. Res. Lett., 28, 1479-1482, doi:10.1029/2000GL012647, 2001.

Kaufman, Y. J., Tanré, D., and Boucher, O.: A satellite view of aerosols in the climate system, Nature, 419, 215-223, 2002.

Kaufman, Y. J., Koren, I., Remer, L. A., Tanré, D., Ginoux, P., and Fan, S.: Dust transport and deposition observed from the Terra-Moderate Resolution Imaging Spectroradiometer (MODIS) spacecraft over the Atlantic Ocean, J. Geophys. Res., 110, D10S12, doi:10.1029/2003JD004436, 2005.

Kinne, S., Schulz, M., Textor, C., Guibert, S., Balkanski, Y., Bauer, S. E., Berntsen, T., Berglen, T. F., Boucher, O., Chin, M., Collins, W., Dentener, F., Diehl, T., Easter, R., Feichter, J., Fillmore, D., Ghan, S., Ginoux, P., Gong, S., Grini, A., Hendricks, J., Herzog, M., Horowitz, L., Isaksen, I., Iversen, T., Kirkevag, A., Kloster, S., Koch, D., Kristjansson, J. E., Krol, M., Lauer, A., Lamarque, J. F., Lesins, G., Liu, X., Lohmann, U., Montanaro, V., Myhre, G., Penner, J. E., Pitari, G., Reddy, S., Seland, O., Stier, P., Takemura, T., and Tie, X.: An AeroCom initial assessment - optical properties in aerosol component modules of global models, Atmos. Chem. Phys, 6, 1815-1834, doi:10.5194/acp-6-1815-2006, 2006.

Kohfeld, K. and Harrison, S. P.: DIRTMAP: The geologic record of dust, Earth Sci., 54, 81-114, 2001.

Li, J. and Barker, H. W.: A radiation algorithm with correlated kdistribution. Part I: local thermal equilibrium, J. Atmos. Sci., 62, 286-309, 2005.

Li, J., Wong, J. G. D., Dobbie, J. S., and Chýlek, P.: Parameterization of the optical properties of sulfate aerosols, J. Atmos. Sci., 58, 193-209, 2001.

Li, Z., Chen, H., Cribb, M., Dickerson, R., Holben, B., Li, C., Lu, D., Luo, Y., Maring, H., Shi, G., Tsay, S. C., Wang, P., Wang, Y., Xia, X., Zheng, Y., Yuan, T., and Zhao, F.: Preface to special section on East Asian Studies of Tropospheric Aerosols: An International Regional Experiment (EAST-AIRE), J. Geophys. Res., 112, D22S00, doi:10.1029/2007JD008853, 2007a.

Li, Z., Xia, X., Cribb, M., Mi, W., Holben, B., Wang, P., Chen, H., Tsay, S. C., Eck, T. F., Zhao, F., Dutton, E. G., and Dickerson, R. E.: Aerosol optical properties and their radiative effects in northern China, J. Geophys. Res., 112, D22S01, doi:10.1029/2006JD007382, 2007b.

Liu, D., Wang, Z., Liu, Z., Winker, D., and Trepte, C.: A height resolved global view of dust aerosols from the first year CALIPSO lidar measurements, J. Geophys. Res., 113, D16214, doi:10.1029/2007JD009776, 2008.
Loeb, N. G. and Smith, N. M.: Top-of-atmosphere direct radiative effect of aerosols over global oceans from merged CERES and MODIS observations, J. Climate, 18, 3506-3526, 2005.

Loeb, N. G., Kato, S., Loukachine, K., and Smith, N. M.: Angular distribution models for top-of-atmosphere radiative flux estimation from the Clouds and the Earth's Radiant Energy System instrument on the Terra satellite. Part 1: Methodology, J. Ocean Atmos. Tech., 22, 338-351, 2005.

Lohmann, U., Von Salzen, K., McFarlane, N., Leighton, H. G., and Feichter, J.: The tropospheric sulfur cycle in the Canadian general circulation model, J. Geophys. Res., 104, 26833-26858, doi:10.1029/1999JD900343, 1999.

Ma, X., von Salzen, K., and Li, J.: Modelling sea salt aerosol and its direct and indirect effects on climate, Atmos. Chem. Phys., 8, 1311-1327, doi:10.5194/acp-8-1311-2008, 2008.

Mahowald, N., Kohfeld, K., Hansson, M., Balkanski, Y., Harrison, S. P., Prentice, I. C., Schulz, M., and Rodhe, H.: Dust sources and deposition during the last glacial maximum and current climate: A comparison of model results with paleodata from ice cores and marine sediments, J. Geophys. Res., 104, 15895-15916, doi:10.1029/1999JD900084, 1999.

Mahowald, N. M., Engelstaedter, S., Luo, C., Sealy, A., Artaxo, P., Benitez-Nelson, C., Bonnet, S., Chen, Y., Chuang, P. Y., Cohen, D. D., Dulac, F., Herut, B., Johansen, A. M., Kubilay, N., Losno, R., Maenhaut, W., Paytan, A., Prospero, J. A., Shank, L. M., and Siefert, R. L.: Atmospheric Iron Deposition: Global Distribution, Variability, and Human Perturbations, Annu. Rev. Mar. Sci., 1, 245-278, doi:10.1146/annurev.marine.010908.163727, 2009.

Mahowald, N. M., Kloster, S., Engelstaedter, S., Moore, J. K., Mukhopadhyay, S., McConnell, J. R., Albani, S., Doney, S. C., Bhattacharya, A., Curran, M. A. J., Flanner, M. G., Hoffman, F. M., Lawrence, D. M., Lindsay, K., Mayewski, P. A., Neff, J., Rothenberg, D., Thomas, E., Thornton, P. E., and Zender, C. S.: Observed 20th century desert dust variability: impact on climate and biogeochemistry, Atmos. Chem. Phys, 10, 1087510893, doi:10.5194/acpd-10-12585-2010, 2010.

Marticorena, B. and Bergametti, G.: Modeling the atmospheric dust cycle: 1 . Design of a soil-derived dust emission scheme, J. Geophys. Res., 100, 16415-16430, doi:10.1029/95JD00690, 1995.

Marticorena, B., Bergametti, G., Aumont, B., Callot, Y., N'Doume, C., and Legrand, M.: Modeling the atmospheric dust cycle: 2. Simulation of Saharan dust sources, J. Geophys. Res., 102, 43874404, doi:10.1029/96JD02964, 1997.

McFarlane, S. A., Kassianov, E. I., Barnard, J., Flynn, G., and Ackerman, T. P.: Surface shortwave aerosol radiative forcing during the Atmospheric Radiation Measurement Mobile Facility deployment in Niamey, Niger, J. Geophys. Res., 114, D00E06, doi:10.1029/2008JD010491, 2009.

Merryfield, W., Denis, B., Fontecilla, J.-S., Lee, W.-S., Kharin, V., Hodgson, J., and Archambault, B.: The Canadian Seasonal to Interannual Prediction System (CanSIPS), Tech. rep., Canadian Meteorological Centre (CMC), 2011.

Merryfield, W. J., McFarlane, N., and Lazare, M.: A generalized hybrid transformation for tracer advection, in: Research Activity in Atmospheric and Oceanic Modelling, CAS/JSC WGNE Blue Book, Report No. 33, 13-14, WMO/TD 1161, Geneva, Switzerland, 2003.

Miller, R. L., Cakmur, R. V., Perlwitz, J., Geogdzhayev, I. V., Ginoux, P., Koch, D., Kohfeld, K. E., Prigent, C., Ruedy, 
R., Schmidt, G. A., and Tegen, I.: Mineral dust aerosols in the NASA Goddard Institute for Space Sciences ModelE atmospheric general circulation model, J. Geophys. Res., 111, D06208, doi:10.1029/2005JD005796, 2006.

Min, Q.-L., Li, R., Lin, B., Joseph, E., Wang, S., Hu, Y., Morris, V., and Chang, F.: Evidence of mineral dust altering cloud microphysics and precipitation, Atmos. Chem. Phys., 9, 3223-3231, doi:10.5194/acp-9-3223-2009, 2009.

Moulin, C., Howard, R. G., Banzon, V. F., and Evans, R. H.: Assessment of Saharan dust absorption in the visible from SeaWiFS imagery, J. Geophys. Res., 106, 18239-18249, doi:10.1029/2000JD900812, 2001.

Myhre, G., Bellouin, N., Berglen, T. F., Berntsen, T. K., Boucher, O., Grini, A., Isaksen, S. A., Johnsrud, M., Mishchenko, M. I., F., S., and Tanre, D.: Comparison of the radiative properties and direct radiative effect of aerosols from a global aerosol model and remote sensing data over ocean, Tellus, 59, 115-129, 2007.

Myhre, G., Berglen, T. F., Johnsrud, M., Hoyle, C. R., Berntsen, T. K., Christopher, S. A., Fahey, D. W., Isaksen, I. S. A., Jones, T. A., Kahn, R. A., Loeb, N., Quinn, P., Remer, L., Schwarz, J. P., and Yttri, K. E.: Modelled radiative forcing of the direct aerosol effect with multi-observation evaluation, Atmos. Chem. Phys., 9, 1365-1392, doi:10.5194/acp-9-1365-2009, 2009.

Nyanganyura, D., Maenhaut, W., Mathuthua, M., Makarau, A., and Meixner, F. X.: The chemical composition of tropospheric aerosols and their contributing sources to a continental background site in northern Zimbabwe from 1994 to 2000, Atmos. Environ., 41, 2644-2659, 2007.

Peyridieu, S., Chedin, A., Tanre, D., Capelle, V., Pierangelo, C., Lamquin, N., and Armante, R.: Saharan dust infrared optical depth and altitude retrieved from AIRS: a focus over North Atlantic-comparison to MODIS and CALIPSO, Atmos. Chem. Phys., 10, 1953-1967, doi:10.5194/acp-10-1953-2010, 2010.

Prigent, C., Tegen, I., Aires, F., Marticorena, B., and Zribi, M.: Estimation of the aerodynamic roughness length in arid and semiarid regions over the globe with the ERS scatterometer, J. Geophys. Res., 110, D09205, doi:10.1029/2004JD005370, 2005.

Prospero, J. M.: Particle flux in the ocean, in: The atmospheric transport of particles to the ocean, edited by: Ittekott, V., Schäfer, P., Honjo, S., and Depetris, P., John Wiley \& Sons, Chichester, 19-52, 1996.

Prospero, J. M.: Long-term measurements of the transport of African mineral dust to the southeastern United States: Implications for regional air quality, J. Geophys. Res., 104, 1591715927, doi:10.1029/1999JD900072, 1999.

Reader, M. C., Fung, I., and McFarlane, N.: The Mineral dust aerosol cycle during the last glacial maximum, J. Geophys. Res., 104, 9381-9398, doi:10.1029/1999JD900033, 1999.

Reddy, M. S., Boucher, O., Bellouin, N., Schulz, M., Balkanski, Y., Dufresne, J.-L., and Pham, M.: Estimates of global multicomponent aerosol optical depth and direct radiative perturbation in the Laboratoire de Meteorologie Dynamique general circulation model, J. Geophys. Res., 110, D10S16, doi:10.1029/2004JD004757, 2005.

Remer, L. A., Kaufman, Y. J., Mattoo, S., Chu, D. A., Martins, J. V., Li, R.-R., Ichoku, C., Levy, R. C., Kleidman, R. G., Eck, T. F., Vermote, E., and Holben, B. N.: The MODIS algorithm, products and validation, J. Atmos. Sci., 62, 947-973, 2005.
Rosenfeld, D., Rudich, Y., and Lahav, R.: Desert dust suppressing precipitation: A possible desertification feedback loop, P. Natl. Acad. Sci., 98, 5975-5980, 2001.

Rotstayn, L. D., Collier, M. A., Mitchell, R. M., Qin, Y., Campbell, S. K., and Dravitzki, S. M.: Simulated enhancement of ENSOrelated rainfall variability due to Australian dust, Atmos. Chem. Phys., 11, 6575-6592, doi:10.5194/acp-11-6575-2011, 2011.

Sassen, K.: Indirect climate forcing over the western US from Asian dust storms, Geophys. Res. Lett., 29, 1465, doi:10.1029/2001GL014051, 2002.

Schulz, M., Textor, C., Kinne, S., Balkanski, Y., Bauer, S., Berntsen, T., Berglen, T., Boucher, O., Dentener, F., Guibert, S., Isaksen, I. S. A., Iversen, T., Koch, D., Kirkeväg, A., Liu, X., Montanaro, V., Myhre, G., Penner, J. E., Pitari, G., Reddy, S., Seland, O., Stier, P., and Takemura, T.: Radiative forcing by aerosols as derived from the AeroCom present-day and pre-industrial simulations, Atmos. Chem. Phys., 6, 5225-5246, doi:10.5194/acp-65225-2006, 2006.

Seinfeld, J. H., Carmichael, G. R., Arimoto, R., Conant, W. C., Brechtel, F. J., Bates, T. S., Cahill, T. A., Clarke, A. D., Doherty, S. J., Flatau, P. J., Huebert, B. J., Kim, J., Markowicz, K. M., Quinn, P. K., Russell, L. M., Russell, P. B., Shimizu, A., Shinozuka, Y., Song, C. H., Tang, Y., Uno, I., Vogelmann, A. M., Weber, R. J., Woo, J.-H., and Zhang, X. Y.: ACE-ASIA: Regional Climatic and Atmospheric Chemical Effects of Asian Dust and Pollution, B. Am. Meteorol. Soc., 85, 367-380, 2004.

Shao, Y., Yang, Y., Wang, J., Song, Z., Leslie, L. M., Dong, C., Zhang, Z., Lin, Z., Kanai, Y., Yabuki, S., and Chun, Y.: Northeast Asian dust storms: Real-time numerical predictions and validation, J. Geophys. Res., 108, 4691, doi:10.1029/2003JD003667, 2003.

Slingo, A., Ackerman, T. P., Allan, R. P., Kassianov, E. I., McFarlane, S. A., Robinson, G. J., Barnard, J. C., Miller, M. A., Harries, J. E., Russel, J. E., and Dewitte, S.: Observations of the impact of a major Saharan dust storm on the atmospheric radiation balance, Geophys. Res. Lett., 33, L24817, doi:10.1029/2006GL027869, 2006.

Solomon, S., Qin, D., Manning, M., Chen, Z., Marquis, M., Averyt, K., Tignor, M., and Miller, H. E.: Climate Change 2007: The Physical Basis. Contribution of Working Group I to the Fourth Assessment Report of the Intergovernmental Panel on Climate Change, Cambridge Univ. Press, Cambridge, UK and New York, USA, 996 pp., 2007.

Stier, P., Feichter, J., Kinne, S., Kloster, S., Vignati, E., Wilson, J., Ganzeveld, L., Tegen, I., Werner, M., Balkanski, Y., Schulz, M., Boucher, O., Minikin, A., and Petzold, A.: The aerosol-climate model ECHAM5-HAM, Atmos. Chem. Phys., 5, 1125-1156, doi:10.5194/acp-5-1125-2005, 2005.

Sullivan, R. C., Moore, M. J. K., Petters, M. D., Kreidenweis, S. M., Roberts, G. C., and Prather, K. A.: Effect of chemical mixing state on the hygroscopicity and cloud nucleation properties of calcium mineral dust particles, Atmos. Chem. Phys., 9, 33033316, doi:10.5194/acp-9-3303-2009, 2009.

Tanaka, T. Y. and Chiba, M.: A numerical study of the contributions of dust source regions to the global dust budget, Global Planet. Change, 52, 88-104, 2006.

Tegen, I. and Fung, I.: Modeling of mineral dust in the atmosphere: Sources, transport, and optical thickness, J. Geophys. Res., 99, 22897-22914, doi:10.1029/94JD01928, 1994. 
Tegen, I., Harrison, S. P., Kohfeld, K., and Prentice, I. C.: Impact of vegetation and preferential source areas on global dust aerosol: Results from a model study, J. Geophys. Res., 107, 4576, doi:10.1029/2001JD000963, 2002.

Textor, C., Schulz, M., Guibert, S., Kinne, S., Balkanski, Y., Bauer, S., Berntsen, T., Berglen, T., Boucher, O., Chin, M., Dentener, F., Diehl, T., Easter, R., Feichter, H., Fillmore, D., Ghan, S., Ginoux, P., Gong, S., Grini, A., Hendricks, J., Horowitz, L., Huang, P., Isaksen, I., Iversen, T., Kloster, S., Koch, D., Kirkevag, A., Kristjansson, J. E., Krol, M., Lauer, A., Lamarque, J. F., Liu, X., Montanaro, V., Myhre, G., Penner, J., Pitari, G., Reddy, S., Seland, O., Stier, P., Takemura, T., and Tie, X.: Analysis and quantification of the diversities of aerosol life cycles within AeroCom, Atmos. Chem. Phys., 6, 1777-1813, doi:10.5194/acp-6-1777-2006, 2006.

Textor, C., Schulz, M., Guibert, S., Kinne, S., Balkanski, Y., Bauer, S., Berntsen, T., Berglen, T., Boucher, O., Chin, M., Dentener, F., Diehl, T., Feichter, J., Fillmore, D., Ginoux, P., Gong, S., Grini, A., Hendricks, J., Horowitz, L., Huang, P., Isaksen, I. S. A., Iversen, T., Kloster, S., Koch, D., Kirkevåg, A., Kristjansson, J. E., Krol, M., Lauer, A., Lamarque, J. F., Liu, X., Montanaro, V., Myhre, G., Penner, J. E., Pitari, G., Reddy, M. S., Seland, Ø., Stier, P., Takemura, T., and Tie, X.: The effect of harmonized emissions on aerosol properties in global models an AeroCom experiment, Atmos. Chem. Phys., 7, 4489-4501, doi:10.5194/acp-7-4489-2007, 2007.

Timmreck, C. and Schulz, M.: Significant dust simulation differences in nudged and climatological operation mode of the AGCM ECHAM, J. Geophys. Res., 109, D13202, doi:10.1029/2003JD004381, 2004.

van Donkelaar, A., Martin, R. V., and Park, R. J.: Estimating ground-level $\mathrm{PM}_{2.5}$ using aerosol optical depth determined from satellite remote sensing, J. Geophys. Res., 111, D21201, doi:10.1029/2005JD006996, 2006.

van Donkelaar, A., Martin, R. V., Brauer, M., Kahn, R., Levy, R., Verduzco, C., and Villeneuve, P. J.: Global estimates of ambient fine particulate matter concentrations from satellite-based aerosol optical depth: Development and application, Environ. Health Persp., 118, 847-855, doi:10.1289/ehp.0901623, 2010.

Vanderzalm, J. L., Hooper, M. A., Ryan, B., Maenhaut, W., Martin, P., Rayment, P. R., and Hooper, B. M.: Impact of seasonal biomass burning on air quality in the "Top End" of regional Northern Australia, Clean Air and Environmental Quality, 37, 28-34, 2003.

Verseghy, D. L.: CLASS: A Canadian Land Surface Scheme for GCMs. I. Soil model, Int. J. Climatol., 11, 111-133, 1991.

von Salzen, K.: Piecewise log-normal approximation of size distributions for aerosol modelling, Atmos. Chem. Phys., 6, 13511372, doi:10.5194/acp-6-1351-2006, 2006.

von Salzen, K., Leighton, H. G., Ariya, P. A., Barrie, L. A., Gong, S. L., Blanchet, J. P., Spacek, L., Lohmann, U., and Kleinman, L. I.: The sensitivity of sulphate aerosol size distributions and $\mathrm{CCN}$ concentrations over North America to $\mathrm{SO}_{\mathrm{x}}$ emissions and $\mathrm{H}_{2} \mathrm{O}_{2}$ concentrations, J. Geophys. Res., 105, 9741-9766, doi:10.1029/2000JD900027, 2000. von Salzen, K., McFarlane, N. A., and Lazare, M.: The role of shallow low convection in the water and energy cycles of the atmosphere, Clim. Dynam., 25, 671-699, 2005.

Wang, A., Price, D. T., and Arora, V.: Estimating changes in global vegetation cover (1850-2100) for use in climate models, Global Biogeochem. Cy., 20, GB3028, doi:10.1029/2005GB002514, 2006.

Wehner, B., Wiedensohler, A., Tuch, T. M., Wu, Z. J., Hu, M., Slanina, J., and Kiang, C. S.: Variability of the aerosol number size distribution in Beijing, China: new particle formation, dust storms, and high continental background, Geophys. Res. Lett., 31, L22108, doi:10.1029/2004GL021596, 2004.

Wehner, B., Birmili, W., Ditas, F., Wu, Z., Hu, M., Liu, X., Mao, J., Sugimoto, N., and Wiedensohler, A.: Relationships between submicronmeter particulate air pollution and air mass history in Beijing, China, 2004-2006, Atmos. Chem. Phys., 8, 6155-6168, doi:10.5194/acp-8-6155-2008, 2008.

Yu, H., Kaufman, Y. J., Chin, M., Feingold, G., Remer, L. A., Anderson, T. L., Balkanski, Y., Bellouin, N., Boucher, O., Christopher, S., DeCola, P., Kahn, R., Koch, D., Loeb, N., Reddy, M. S., Schulz, M., Takemura, T., and Zhou, M.: A review of measurement-based assessments of the aerosol direct radiative effect and forcing, Atmos. Chem. Phys., 6, 613-666, doi:10.5194/acp-6-613-2006, 2006.

Yu, H., Chin, M., Winker, D. M., Omar, A. H., Liu, Z., Kittaka, C., and Diehl, T.: Global view of aerosol vertical distributions from CALIPSO lidar measurements and GOCART simulations: Regional and seasonal variations, J. Geophys. Res., 115, D00H30, doi:10.1029/2009JD013364, 2010.

Yue, D., Hu, M., Wu, Z., Wang, Z., Guo, S., Wehner, B., Nowak, A., Achtert, P., Wiedensohler, A., Jung, J., Young, K. J., and Liu, S.: Characteristics of aerosol size distributions and new particle formation in the summer in Beijing, J. Geophys. Res., 114, D00G12, doi:10.1029/2008JD010894, 2009.

Zender, C. S., Miller, R. L., and Tegen, I.: Quantifying mineral dust mass budgets: terminology, constraints, and current estimates, Eos Trans. AGU, 85, 509-512, doi:10.1029/2004EO480002, 2004.

Zhang, G. J. and McFarlane, N. A.: Sensitivity of climate simulations to the parameterization of cumulus convection in the Canadian Climate Centre General Circulation Model, Atmos. Ocean, 33, 407-446, 1995.

Zhang, L.-M., Gong, S.-L., Padro, J., and Barrie, L.: A sizesegregated particle dry deposition scheme for an atmospheric aerosol module, Atmos. Environ., 35, 549-560, 2001.

Zhao, X.-P., Loeb, N. G., Laszlo, I., and Zhou, M.: Global component aerosol direct radiative effect at the top of atmosphere, Int. J. Remote Sens., 32, 633-655, 2010.

Zobler, L.: A world soil file for global climate modeling, Tech. Rep. 87802, Tech. Rep. NASA, 1986. 